\title{
Design of Gasifiers to Optimize Fuel Cell Systems
}

\author{
Final Report \\ September 1990 - September 1993
}

August 1993

Work Performed Under Contract No.: DE-AC21-90MC27227

\section{For}

U.S. Department of Energy

Office of Fossil Energy

Morgantown Energy Technology Center

Morgantown, West Virginia

By

Energy Research Corporation

Danbury, Connecticut 


\section{DISCLAIMER}

This report was prepared as an account of work sponsored by an agency of the United States Government. Neither the United States Government nor any agency thereof, nor any of their employees, makes any warranty, express or implied, or assumes any legal liability or responsibility for the accuracy, completeness, or usefulness of any information, apparatus, product, or process disclosed, or represents that its use would not infringe privately owned rights. Reference herein to any specific commercial product, process, or service by trade name, trademark, manufacturer, or otherwise does not necessarily constitute or imply its endorsement, recommendation, or favoring by the United States Government or any agency thereof. The views and opinions of authors expressed herein do not necessarily state or reflect those of the United States Government or any agency thereof.

This report has been reproduced directly from the best available copy,

Available to DOE and DOE contractors from the Office of Scientific and Technical Information, P.O. Box 62, Oak Ridge, TN 37831; prices available from (615) 576-8401.

Available to the public from the National Technical Information Service, U.S. Department of Commerce, 5285 Port Royal Rd., Springfield, VA 22161, (703) $487-4650$. 


\title{
Design of Gasifiers to Optimize Fuel Cell Systems
}

Final Report

September 1990 - September 1993

Work Performed Under Contract No.: DE-AC21-90MC27227

\author{
For \\ U.S. Department of Energy \\ Office of Fossil Energy \\ Morgantown Energy Technology Center \\ P.O. Box 880 \\ Morgantown, West Virginia 26507-0880
}

\author{
By \\ Energy Research Corporation \\ 3 Great Pasture Road \\ Danbury, Connecticut 06813
}

August 1993 
i 


\section{DISCLAIMER}

This report was prepared as an account of work sponsored by an agency of the United States Government. Neither the United States Government nor any agency thereof, nor any of their employees, make any warranty, express or implied, or assumes any legal liability or responsibility for the accuracy, completeness, or usefulness of any information, apparatus, product, or process disclosed, or represents that its use would not infringe privately owned rights. Reference herein to any specific commercial product, process, or service by trade name, trademark, manufacturer, or otherwise does not necessarily constitute or imply its endorsement, recommendation, or favoring by the United States Government or any agency thereof. The views and opinions of authors expressed herein do not necessarily state or reflect those of the United States Government or any agency thereof. 


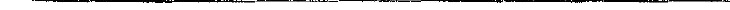




\section{DISCLAIMER}

Portions of this document may be illegible in electronic image products. Images are produced from the best available original document. 



\section{ACKNOWLEDGEMENTS}

This effort was conducted by Energy Research Corporation (ERC) in collaboration with Fluor Daniel and the University of North Dakota/Energy \& Environmental Research Center (UND/EERC) under the direction of the U.S. Department of Energy Morgantown Energy Technology Center (DOE/METC). The DOE/METC project manager is Mr. Justin Beeson.

Fluor Daniel conducted the detailed system configuration and analysis. The Fluor project manager was Thurle Moss, and principal investigators were Steven J. Meyers and Arthur Lee. The University of North Dakota/Energy \& Environmental Research Center evaluated options for disposable gasification catalysts. UND/EERC also carried out TGA and bench-scale testing of gasification catalysts. The UND/EERC project manager was William B. Hauserman, with principal investigators Everett A. Sondreal, Warrack G. Willson, Steve Cisney, and Ron Timpe.

Energy Research Corporation was over-all project coordinator and provided fuel cell performance data for the carbonate fuel cell system and the Hydrogen Transfer Device (HTD), as well as recommendations for system configurations. ERC participants included Dr. Bernard Baker, Dr. Hans Maru, A. Kush, and Jennifer Fruchtman who prepared this final report.

In addition to the project participants mentioned above, a Utility Advisory Committee consisting of representatives from Electric Power Research Institute (EPRI), Southern Company Services Inc., Dakota Gasification Company and DOE were consulted. These advisors included Mr. Neville A. Holt of EPRI, Mr. Rodney E. Sears of Southern Company Services, Mr. Donald C. Pollock of Dakota Gasification Company and Mr. Lawrence K. Rath of DOE/METC. 


\section{EXECUTIVE SUMMARY}

Pursuing the key national goal of clean and efficient utilization of the abundant domestic coal resources for power generation, this study was conducted to evaluate the potential of optimizing the integrated catalytic gasification/carbonate fuel cell power generation system.

ERC, in close collaboration with Fluor Daniel (providing engineering design and costing), conducted a detailed system configuration study under DOE/METC Contract No. DE-AC21-90MC27227 to evaluate various catalytic gasification/carbonate fuel cell power plant configurations and compare them to present day, as well as emerging, alternate coal-based power plant technologies to assess their competitive position. A Topical Report (1992) was submitted documenting this effort, and the three catalytic gasification case studies are summarized in Appendix A.

Results of this study indicate that system efficiencies approaching $55 \%$ (HHV) can be achieved by integrating low temperature catalytic gasification with high efficiency carbonate fuel cells. Thermal balance in the gasifier is achieved without oxygen by recycling hydrogen from the fuel cell anode exhaust. A small amount of air is added to the gasifier to minimize hydrogen recycle.

In order to validate the assumptions made in the case configurations, experimental studies were performed to determine the reactivity of Illinois No. 6 coal with the gasification catalysts. The reactivity of the catalyzed coal has significant bearing on gasifier sizing and hence system cost and efficiency.

Experimental testing was conducted at University of North Dakota Energy \& Environmental Research Center. An initial screening to determine the steam-char reactivities at atmospheric pressure of Illinois No. 6 with dry and impregnated forms of potassium, calcium and iron was performed using Thermogravimetric Analysis (TGA). The highest reactivities were obtained using dry or impregnated potassium $\left(\mathrm{K}_{2} \mathrm{CO}_{3}\right)$; these results were very similar, indicating that potassium addition in dry form becomes very mobile. Calcium catalyzed reactivity was found to be lower than that for potassium, but potential exists for improvement by impregnation of soluble calcium. The results showed that the reactivity of llinois No. 6 and dry calcium was up to $64 \%$ higher than the reactivity obtained with Illinois No. 6 alone (with no catalyst). Previously obtained data using a different batch of calcium catalyzed llinois No. 6 coal resulted in significantly higher (by a factor of 4) reactivity with dry calcium. This indicates that variability exists among coals of the same rank. Impregnating llinois No.6 with calcium increases the reactivity nearly three-fold compared to dry calcium addition due to improved distribution and may be a viable option for using this disposable catalyst. This indicates that calcium is not very mobile and therefore uniform distribution is important for good reactivity.

Integrated Batch Gasifier (IBG) testing was performed on Illinois No.6 impregnated with $\mathrm{K}_{2} \mathrm{CO}_{3}$. This fluidized bed batch gasifier provides data on the effects of bed fluidization, coal conversion, product yields and reaction rate as a function of gasifier operating conditions in a cost-effective manner. 
These bench-scale test results showed that reactivity with potassium catalyst increased with increasing pressure and temperature. Reactivities obtained at elevated pressure (150 psig) approach reactivities obtained with TGA data (atmospheric), implying that at the system conditions of 750 psig, reactivity would exceed TGA reactivity by a considerable margin. This has an impact on the calcium catalyzed system cases studied which used TGA reactivity data for gasifier design. Bench-scale testing of calcium catalyzed coal at elevated pressures is therefore expected to show improved reactivity thereby improving the efficiency and economics of calcium based catalytic gasification/fuel cell systems.

Larger scale testing is required to demonstrate the viability of catalytic gasification, followed by tests integrating carbonate fuel cells. The results of the system studies and experimental work conducted are encouraging for high efficiency power generation system from coal. Efficiency improvements of up to $40 \%$ compared to commercial PC and AFBC systems were estimated. Compared to IGCC, a $32 \%$ improvement is projected. The experimental results have provided direction for continued effort for an economical catalytic gasification system. Additional efforts in catalyst studies are therefore recommended. 


\section{ACKNOWLEDGEMENTS}

EXECUTIVE SUMNIARY

1.0 INTRODUCTION

2.0 METHODOLOGY

3.1 BACKGROUND 5

$\begin{array}{lll}3.2 & \text { EXPERIMENTAL STUDIES } & 8\end{array}$

$\begin{array}{lll}\text { 3.2.1 TGA TESTING } & 8\end{array}$

3.2.2 INTEGRATED BENCH-SCALE GASIFIER TESTING REACTIVITY MEASUREMENTS

4.0 CONCLUSIONS

$\begin{array}{ll}\text { REFERENCES } & 27\end{array}$ 


\section{LIST OF TABLES}

IITLE

PAGE

Table 1 Environmental Impact Comparison with Competing Systems

Table 2 Reactivities of Illinois No. 6 Determined by TGA Analysis at Atmospheric Pressure

Table 3 Comparison of System Study and TGA Reactivities

Table 4 Proximate and Ultimate Analysis of Washed and Potassium-Impregnated Illinois No.6 Coal

Table 5 Reactivities of Potassium-Impregnated Illinois No. 6 Coal k, $(\mathrm{l} / \mathrm{h})$

Table 6 IBG Product Gas Composition and Equilibrium Composition

Table 7 Potassium Recovery from Leached Gasifier Residue 


\section{LIST OF FIGURES}

TITLE

PAGE

Figure 1 Gasifier/Carbonate Fuel Cell Configurations 2

Figure 2 Program Approach 4

$\begin{array}{lll}\text { Figure } 3 & \text { Sample TGA Data Plot } & 10\end{array}$

Figure 4 TGA Reactivity of Illinois No.6 with Gasification Catalysts at Atmospheric Pressure

$\begin{array}{lll}\text { Figure } 5 & 15\end{array}$

$\begin{array}{lll}\text { Figure } 6 & \text { Integrated Bench-Scale Gasifier Schematic } & 16\end{array}$

$\begin{array}{lll}\text { Figure } 7 & \text { FTIR Analysis from IBG Reactivity Comparison } & 17\end{array}$

$\begin{array}{lll}\text { Figure } 8 & \text { Reactivity Determined by Tangent Slope Method } & 18\end{array}$

Figure 9 Reactivity Determined by Whole Exponential Curve

Fit Method

Figure 10 Potassium Catalyzed Illinois No. 6 Bench-Scale Gasification and TGA Reactivities

Figure A-1 Case 1 Process Flow Sketch

Figure A-2 Case 1 Steam Balance Diagram

Figure A-3 Case 2 Process Flow Sketch

Figure A-4 Case 3 Process Flow Sketch 


\subsection{INTRODUCTION}

More than $50 \%$ of the electricity generated in the United States is derived from coal. Although the abundant coal reserves in the U.S. assure us a 400 year supply of this low cost energy source, its utilization in an efficient and environmentally acceptable manner is becoming more critical as energy independence issues become more crucial economically and environmental issues more pressing.

The technologies currently utilized for coal based power generation rely on combustion of coal and flue gas desulfurization. These include Pulverized Coal Combustion Boiler/Flue Gas Desulfurization (PC/FGD), Atmospheric Fluid Bed Combustion (AFBC), and Pressurized Fluid Bed Combustion (PFBC). Although improvements are still being made, these technologies are inherently limited in the efficiencies and emissions achievable. As existing U.S. power plant equipment reaches the end of its useful life, more efficient, lower cost, and environmentally superior replacements will be necessary as we prepare to enter the next century.

The carbonate fuel cell is recognized as a highly efficient power generating device that can also provide environmentally acceptable utilization of coal. Unlike thermomechanical devices such as turbines that convert thermal energy to electricity, the carbonate fuel cell electrochemically converts chemical energy directly to electricity. Coal based use of this technology requires a coal gasification conversion process rather than the conventional coal combustion process. The gasification process offers both efficiency and environmental advantages over the combustion process.

Conventional gasification systems were developed based on the requirements of the gasification process itself. The process requires high temperatures for complete hydrocarbon conversion in order to produce a tar-free gas. These high temperatures are normally achieved by an oxidant fed to the gasifier, which consumes a portion of the coal feed to produce the needed heat. In addition, the high gasification temperatures are above those necessary for most end use applications as well as gas cleanup purposes. While practical for syngas production, this results in some efficiency and cost penalties for power production. A typical gasification/carbonate fuel cell configuration for this type of system is illustrated in Figure 1a. The fuel gas is primarily hydrogen, carbon dioxide, and carbon monoxide. Waste heat is converted to steam for the gasifier and the bottoming cycle. A recent DOE/METC supported system study ${ }^{(1)}$ conducted by ERC and Fluor Daniel evaluated a number of systems based on this configuration, and concluded that attractive systems are possible utilizing present day gasifiers.

Catalytic gasification, however, offers the potential for novel approaches to fuel cell integration. By catalyzing the gasification reaction, lower temperatures are sufficient, and use of an oxidant can be minimized while hydrogen recycle to the gasifier is used ${ }^{(2)}$. The lower gasification temperature contributes to improved efficiency and improved thermal integration with the carbonate fuel cell which operates at approximately the same temperature. The recycle requirement to the gasifier can be provided in several ways, as investigated in this and other studies. 


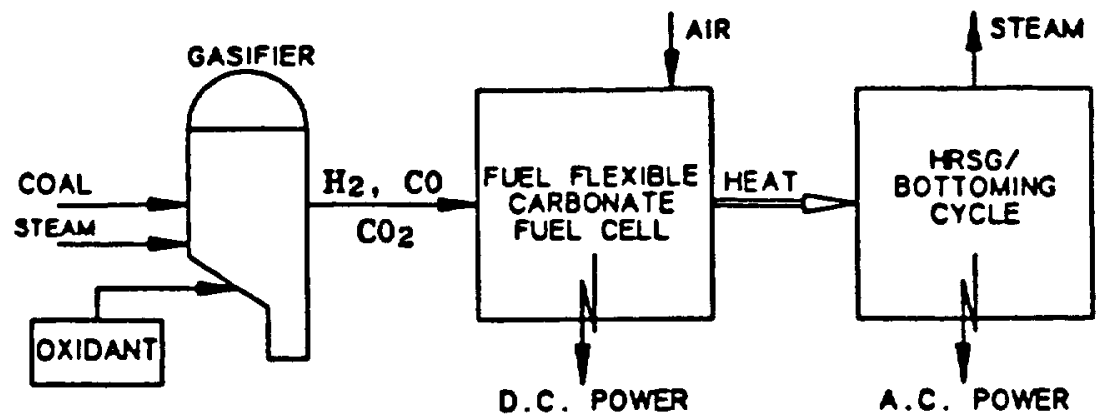

10.) Conventional CGCFC Concept

(Only Thermal Integration)

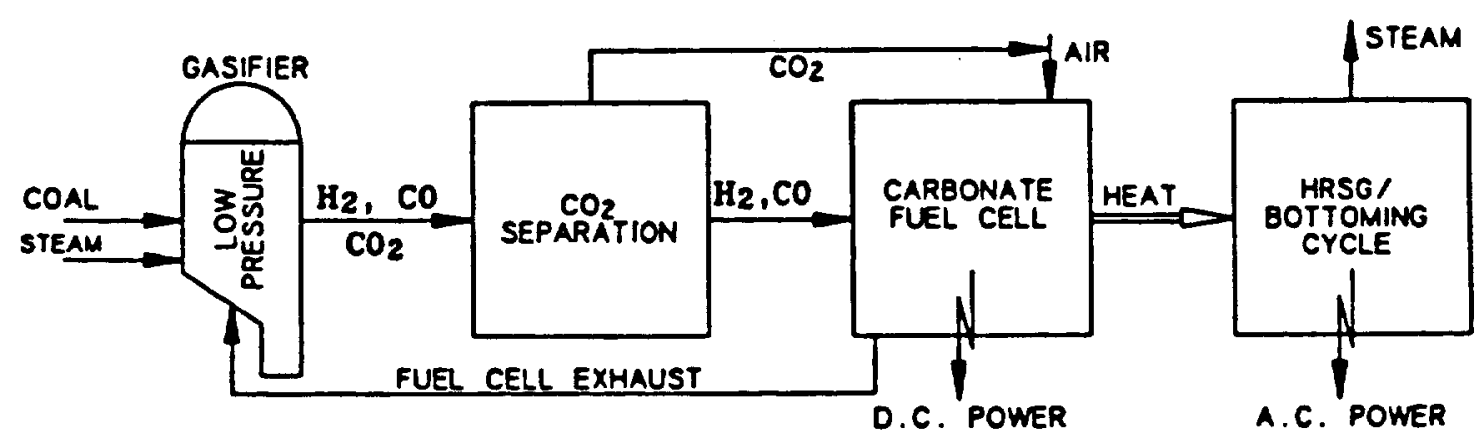

1b.) Advanced Gasification/Carbonate

Fuel Cell System-High-Hydrogen Cose

(Thermochemical Integration)

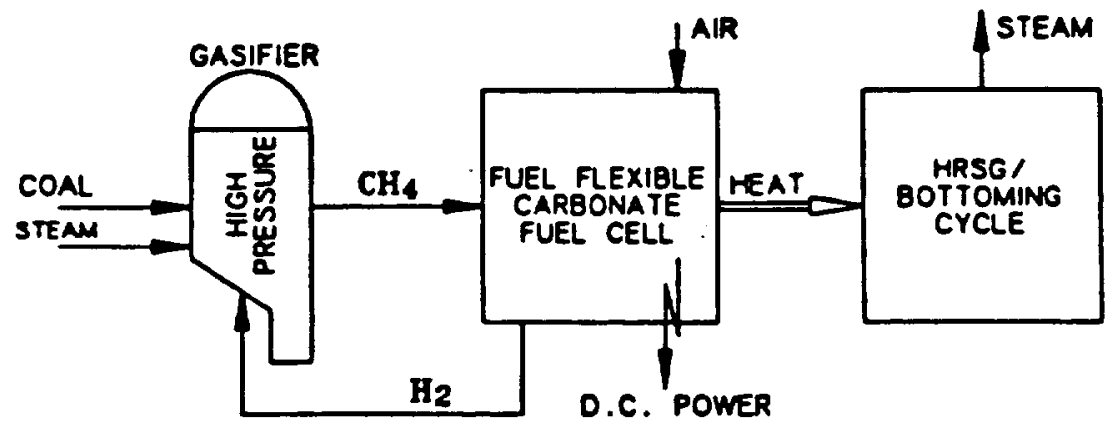

ic.) Advanced Gasification/Carbonate

Fuel Cell System-High-Methane Case (Thermochemical Integration)

LO12040

Figure 1 GASIFIER/CARBONATE FUEL CELL CONFIGURATIONS 
Several studies were conducted to evaluate the integration of catalytic gasification with fuel cells. One such study ${ }^{(3)}$ suggests recycling the fuel cell exhaust back to the gasifier at low pressure. The fuel cell exhaust provides the chemical energy required by the gasifier and increases system efficiency. This approach maximizes hydrogen production by operating the gasifier at low pressure, and separates carbon dioxide for injection into the fuel cell cathode, as shown in Figure 1b. The approach chosen in this program was to recycle hydrogen to the gasifier, which is operating at high pressure, to maximize methane formation, as shown in Figure 1C. Other approaches have been proposed $^{(4)}$ which recycle the anode exhaust to the gasifier at high pressure, permitting gasification at elevated pressure.

This program evaluated the potential of optimizing the integrated catalytic gasification/carbonate fuel cell power generation system in order to improve efficiency and lower costs. In addition, the optimized catalytic gasification/carbonate fuel cell systems were compared to present day as well as emerging alternate coal-based power technologies to assess it's competitive position.

After an initial evaluation of two basic design approaches: recycling anode fuel cell exhaust back to a low pressure gasifier (high hydrogen approach), and recycling only separated hydrogen from the fuel cell to the gasifier (high methane approach), the high methane approach was selected for the design of three case configurations:

Case No. 1 Recoverable Gasification Catalyst with Cold Gas Cleanup Technology Case No. 2 Disposable Gasification Catalyst with Cold Gas Cleanup Technology Case No. 3 Disposable Gasification Catalyst with Hot Gas Cleanup Technology

The results of the case and system comparisons were presented in detail previously(5), and are summarized here. The emphasis of this report is on the experimental studies conducted in order to verify the gasifier kinetics assumed in the case studies.

\subsection{METHODOLOGY}

This program was designed to evaluate the integration of catalytic coal gasification with carbonate fuel cells by adapting the coal gasification system to meet the requirements of the fuel cell. The program logic and methodology is shown in Figure 2.

Three integrated catalytic coal gasification/carbonate fuel cell configurations were developed and evaluated with respect to heat rate, capital cost and relative cost of electricity. A comparison of heat rate and environmental impact of these configurations with conventional coal power generation systems was made.

Experimental studies were performed to assess the impact on kinetics and hence gasifier sizing of the gasification catalysts used in the different cases. A quick screening of the catalysts was performed using Thermogravimetric Analysis. Larger scale testing was performed in a batch gasifier at pressures up to 150 psig. The reactivities determined in these tests were used to check the validity of the assumptions made in the case studies. 


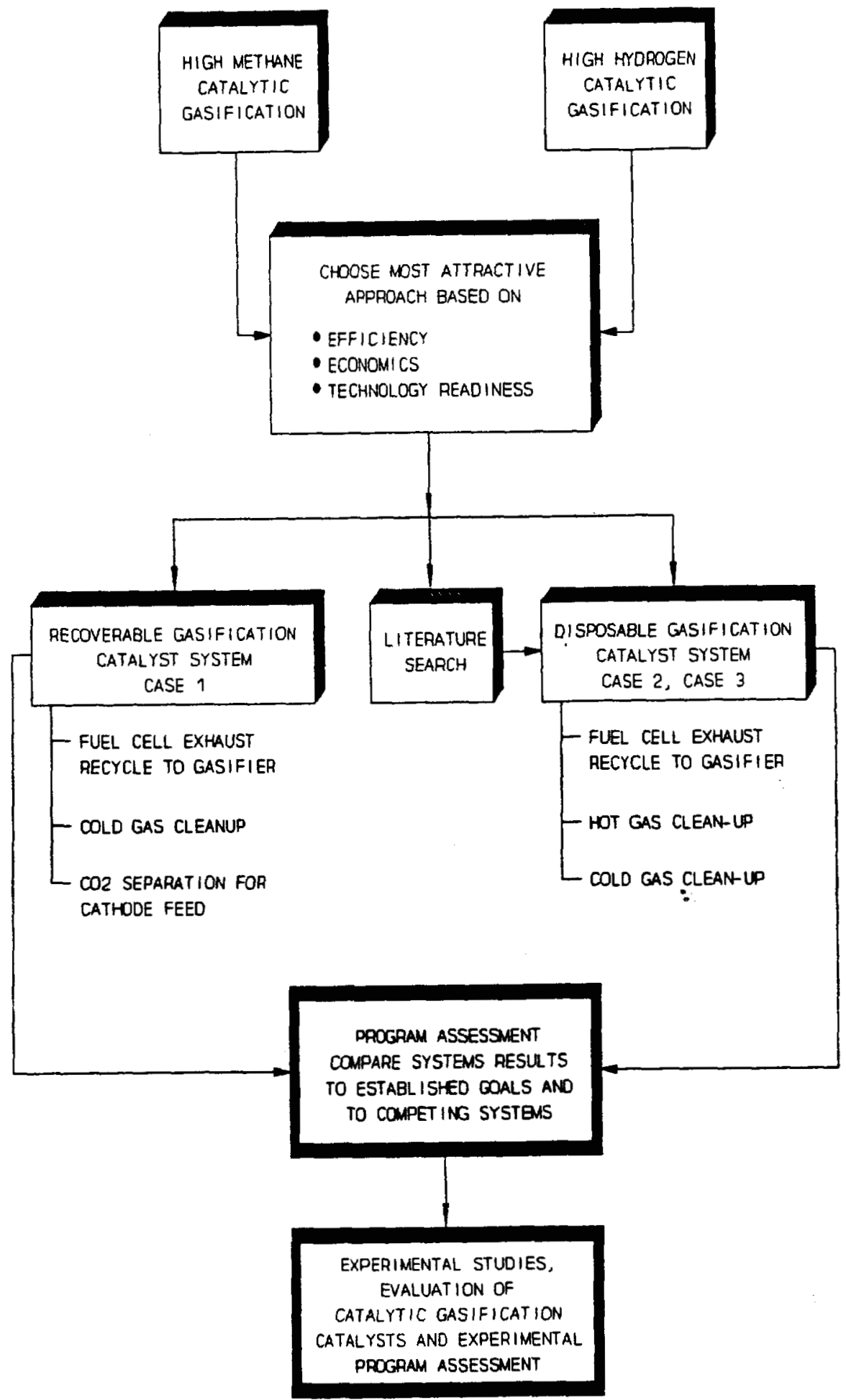

M01110

Figure 2 PROGRAM APPROACH 


\subsection{RESULTS AND DISCUSSION}

\subsection{BACKGROUND}

A $200 \mathrm{MW}$ baseload integrated gasifier/carbonate fuel cell power plant was configured based on an Illinois-Wisconsin area location. It is fueled by lllinois No. 6 bituminous coal and uses catalytic gasification based on the Exxon catalytic process and internal reforming carbonate fuel cells. The results of the three case studies are summarized in Appendix A.

\section{Gasifier/Fuel Cell System Design Studies}

Case 1 uses a recoverable gasification catalyst, $\mathrm{K}_{2} \mathrm{CO}_{3}$, similar to the Exxon system, and is used as a reference case. It results in a system having a heat rate of 6606 $\mathrm{Btu} / \mathrm{kWh}$. Case 2 differs from Case 1 in the use of relatively low cost, disposable limestone $\left(\mathrm{CaCO}_{3}\right)$ as the gasification catalyst instead of recoverable potassium carbonate $\left(\mathrm{K}_{2} \mathrm{CO}_{3}\right)$. The use of a disposable catalyst was intended to lower plant capital cost by eliminating the catalyst recovery equipment and reducing make-up chemical costs. However, this would be offset by an increase in the gasification cost as limestone is generally less effective than $\mathrm{K}_{2} \mathrm{CO}_{3}$ as a gasification catalyst. This system results in a heat rate of $6748 \mathrm{Btu} / \mathrm{kWh}$.

Case 3 is similar to Case 2 with the use of a disposable catalyst, but differs from both Case 1 and 2 by using a hot, zinc ferrite cleanup system. In the hot gas cleanup system, the $1200^{\circ} \mathrm{F}$ gas passes through a ceramic filter and a zinc ferrite sorbent bed to remove the sulfur. The clean fuel is heated and routed to hot fuel gas expansion. The moisture level of this gas is acceptable (35.2\%), and therefore fuel gas moisturization is not required. This system results in the highest efficiency of all three cases, with a heat rate of $6377 \mathrm{Btu} / \mathrm{kWh}$, or $53.5 \%$ efficiency on a higher heating value basis.

\section{System Comparison}

Three competing coal based power generation technologies were selected for comparison purposes to establish the competitive position of the catalytic coal gasification/carbonate fuel cell technology. The selected technologies were:

- Atmospheric Fluidized Bed Combustion (AFBC)

- Pulverized Coal Combustion Boiler/Flue Gas Desulfurization (PC/FGD)

- Integrated Gasification Combined Cycle (IGCC)

Data for this comparison was taken from the 1990 ERC/Fluor ${ }^{(1)}$ study. The performance of all the competing systems was at approximately the same net power production as the three cases configured in this study, $200 \mathrm{MW}$. The technologies were compared on heat rate and environmental impact. 
The heat rate of the three fuel cell case studies range from $36 \%$ to $40 \%$ lower than the pulverized coal with coal cleanup and wet flue gas desulfurization $(6,377-6,748$ versus $10,571 \mathrm{Btu} / \mathrm{kWh})$. The heat rate of the advanced IGCC system ( $8420 \mathrm{Btu} / \mathrm{kWh})$ is 20 to $24 \%$ higher than the heat rate of the three fuel cell case studies.

Today's power generation systems must not only be efficient and cost effective but also environmentally benign. The amount of $\mathrm{SO}_{x}, \mathrm{NO}_{x}$, and $\mathrm{CO}_{2}$ a facility emits, along with the amount of makeup water it uses, are important issues to consider. The environmental impact of the competing technologies are compared to the integrated coal gasification/carbonate fuel cell concept in Table 1.

The sulfur cleanup and recovery system in the integrated coal gasification/carbonate fuel cell technology results in sulfur emissions of less than $0.1 \%$ of the feed $(<0.02 \mathrm{lb} / \mathrm{MWh})$. This is due to the front end desulfurization which is possible when coal is gasified rather than burned. Conventional technologies in use today cannot compare with this low figure, having sulfur emissions ranging up to two orders of magnitude greater. IGCC, while typically is not expected to achieve as low a sulfur emission, is technically capable of achieving the same level. The coal gasification/carbonate fuel system emits much lower levels of $\mathrm{NO}_{\mathrm{x}}$ (trace levels as compared with up to $1.1 \mathrm{lb} / \mathrm{MWh}$ ) due to the minimal combustion occurring in this plant. Carbon dioxide emissions are also lower by $35 \%$ due to the higher efficiency of the integrated catalytic gasification carbonate fuel cell system, compared to the other systems. The makeup water for the case studies, taken from the Case 1 steam balance, was only $20-24 \%$ of the other competing systems, providing for a system with minimal impact on the environment. 


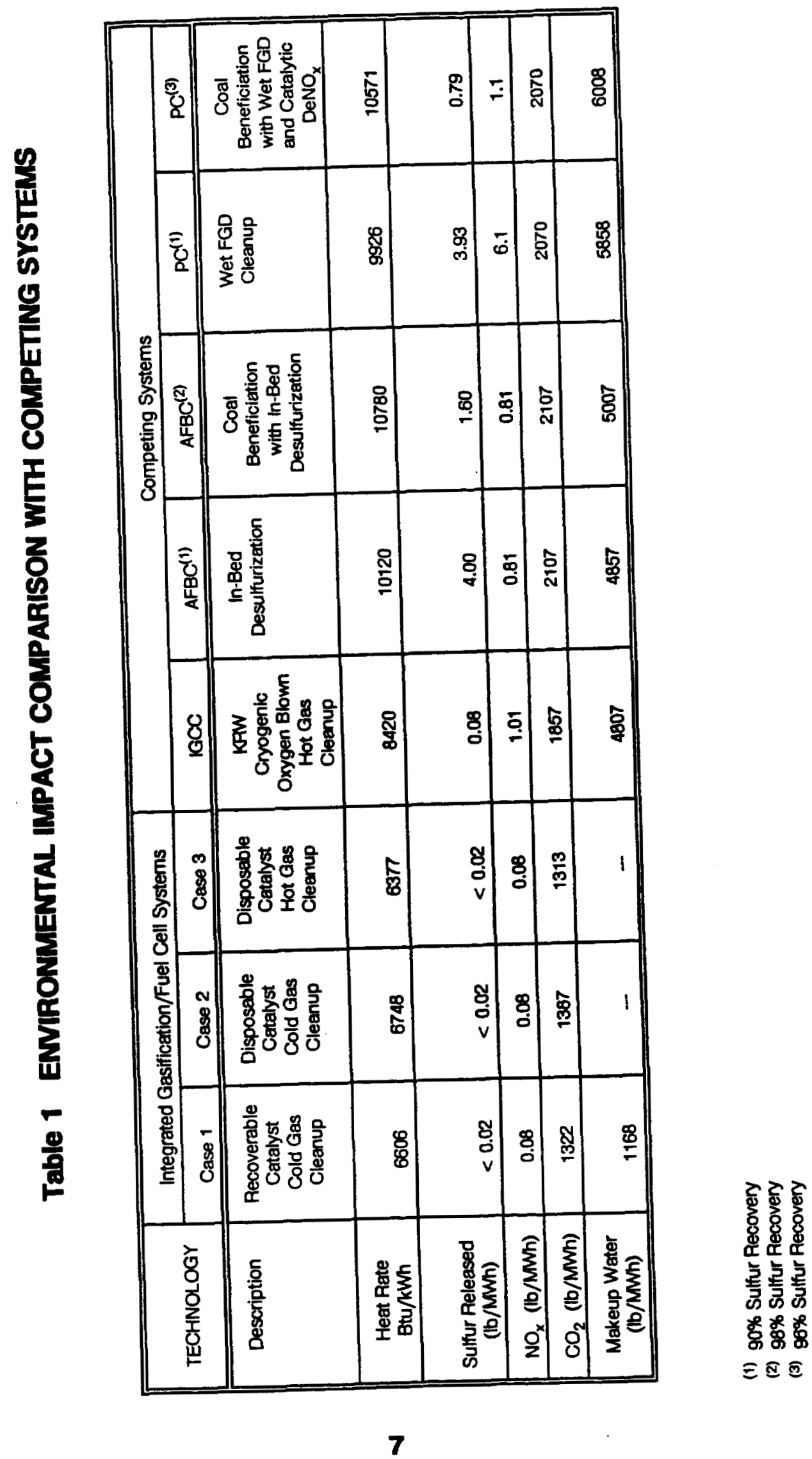




\subsection{EXPERIMENTAL STUDIES}

The major objective of this task was to experimentally characterize the performance of the gasification catalysts recommended in the system studies. These include potassium, limestone and taconite. The reference coal was Illinois No. 6.

The first phase of experimental testing consisted of a cost-effective minimum scale screening by Thermogravimetric Analysis (TGA). The results of these tests were used to predict the overall reactivity and to recommend conditions for the bench-scale testing used in the second phase of the experimental testing.

The Integrated Bench-Scale Gasifier (IBG) was used in the second phase of experimental testing as a transition from TGA results to a continuous gasification system. In the IBG, larger coal samples $(\sim 70 \mathrm{~g})$ are injected into a preheated fluidized bed at pressures ranging up to $150 \mathrm{psig}$. The use of larger samples allows for analysis of residual ash, char and condensible liquid coproducts. The IBG was operated at conditions as close as possible to the system conditions defined in the first year of this effort, but was still significantly below the system pressures of 750 psig.

\subsubsection{TGA TESTING}

The TGA tests are designed to compare steam-char reactivities at atmospheric pressure using illinois No. $6 \mathrm{coal}$ and various catalysts. The gasification reaction order and reactivity is determined by measuring the rate of carbon consumption:

$$
\left(-\frac{d c}{d t}\right)=k C^{n}
$$

where:

$$
\begin{aligned}
\mathrm{dC} / \mathrm{dt} & =\text { rate of carbon disappearance } \\
\mathrm{C} & =\text { amount of carbon present per reacting volume at any instant } \\
\mathbf{k} & =\text { rate constant or reactivity } \\
\mathrm{n} & =\text { order of the reaction }
\end{aligned}
$$

Reaction order is determined from the slope of a log dC/dt vs. $\log C$ plot and typically ranges from 0.5 to 2 for gasification reactions. In the TGA experiments the gasification reaction is forced into a first order reaction due to excess steam addition. Reactivity is determined through integrating the first order reaction and inputting carbon weight loss data:

$$
C(t)=C_{0} e^{-k t}
$$


The gasification catalysts studied were dry and impregnated forms of calcium, iron and potassium. In all cases the molar equivalent ratio of catalyst to fixed carbon was 0.12 , so that for $\mathrm{K}^{+}$the molar ratio was $\mathrm{K} / \mathrm{FC}=0.12$, for $\mathrm{Ca}^{++}=0.06$, and for $\mathrm{Fe}^{+++}=$ $0.04 \mathrm{mols} / \mathrm{mol}$. In this way the active sites on the coal structure $(-\mathrm{COO})$ are exposed to the same number of possible connections with mobile cations, regardless of the choice of metallic element. The weight of the catalysts ranged from $20-29 \%$.

The TGA tests were performed at temperatures ranging from $600^{\circ} \mathrm{C}$ to $800^{\circ} \mathrm{C}$. The sample is placed on the TGA sample pan and heated to the target temperature under an argon flow. During this temperature increase, devolatization occurs producing a char. When the char reaches the target temperature, steam is introduced, the argon flow is decreased, and the char reaction proceeds to completion. Weight, time and temperature are automatically recorded by the TGA data station. An example of a TGA data plot is shown in Figure 3.

The overall reactivities obtained from the TGA data are listed in Table 2 . The reactivity of non-catalyzed Illinois No. 6 ranged from $0.07 \mathrm{~h}^{-1}$ at $700^{\circ} \mathrm{C}$ to $0.33 \mathrm{~h}^{-1}$ at $800^{\circ} \mathrm{C}$. Dry or impregnated taconite provides essentially no catalytic activity; reactivity increased marginally to $0.41 \mathrm{~h}^{-1}$ at $800^{\circ} \mathrm{C}$. Impregnated calcium provides some improvement in reactivity as compared with dry limestone and taconite, increasing reactivity of noncatalyzed coal nearly three-fold to $0.26 \mathrm{~h}^{-1}$ at $700^{\circ} \mathrm{C}$. A second set of data with dry calcium using a different type of Illinois No. 6 resulted in higher reactivity than the impregnated calcium with the original batch of coal. The order of magnitude difference in the two data sets illustrates that TGA data is very coal specific and can reflect differences in mineral content due to variability in the coal and where it is mined. This also indicates that calcium catalyzed reactivity can perhaps be represented by a band rather than a curve, and that higher reactivities are possible approaching the reactivity with potassium. This range is compared with the reactivity obtained with potassium in Figure 4. The highest reactivities were obtained using a potassium catalyst (dry or impregnated), increasing the reactivity of non-catalyzed coal over 100 times to reach 7.33 to $8.55 \mathrm{~h}^{-1}$ at $700^{\circ} \mathrm{C}$. The negligible difference in reactivities of wood ash leachate and $\mathrm{K}_{2} \mathrm{CO}_{3}$ indicate that the potassium is as mobile dry as it is impregnated and therefore its chemical form is not important.

Although reactivity data obtained in TGA experiments is not identical to reactivities obtained in large scale continuous gasifiers, it does provide relative reactivity which can be useful when large scale continuous reactor data is not available. TGA reactivity data is higher than gasifier reactivity data, mainly due to the excess steam addition in TGA experiments which affects reaction order. The trends in reactivity and temperature, however, should remain fairly constant for a given coal; the slopes of the reactivity versus temperature in this effort are in the same range. In the case studies summarized in Appendix A, the reactivity of Illinois No. 6 with calcium catalyst was assumed to be $80 \%$ of previous TGA reactivity data. 


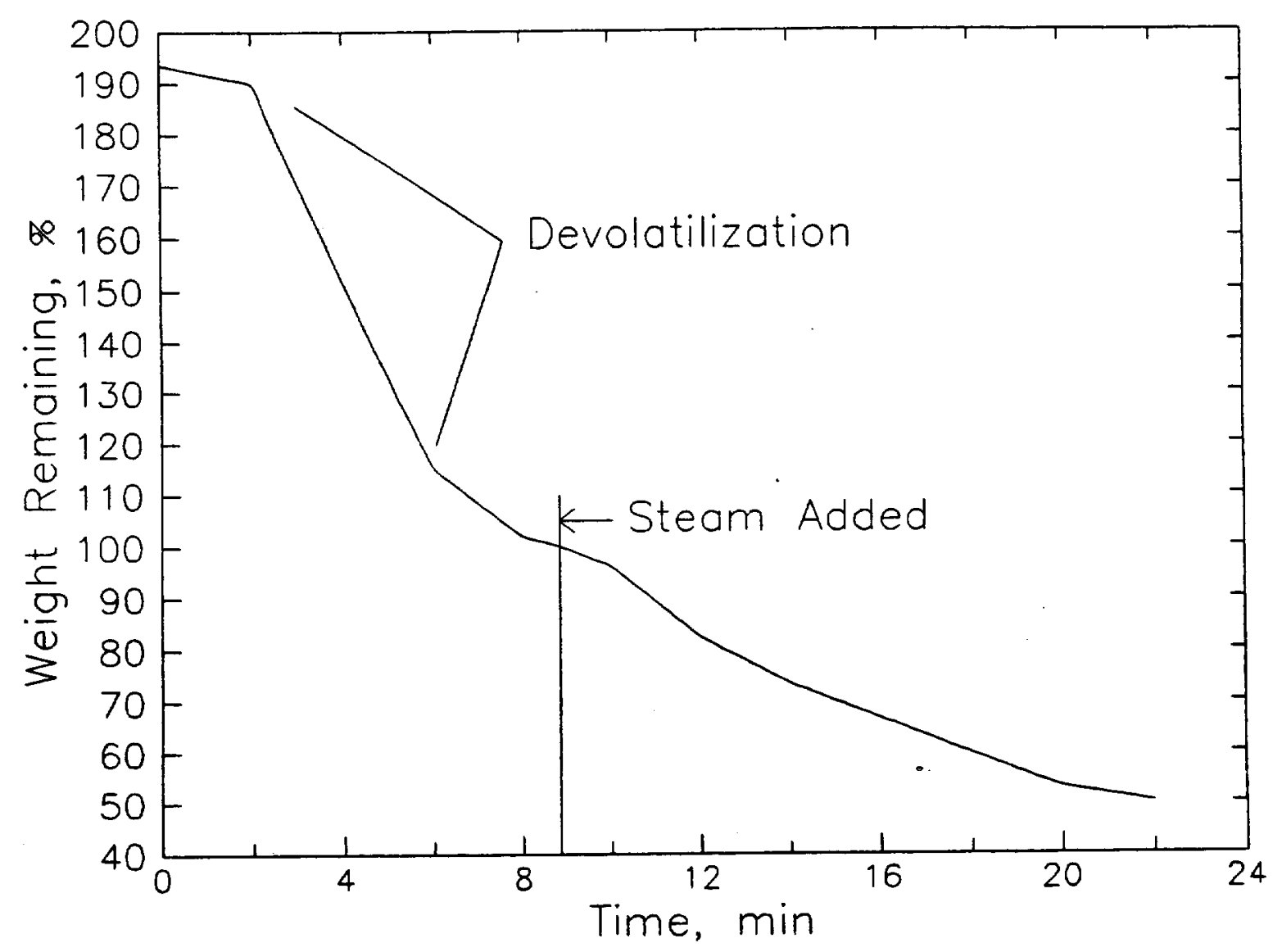

JF0033

Figure 3 SAMPLE TGA DATA PLOT 
Table 2 REACTIVITIES OF ILLINOIS NO. 6 DETERMINED BY TGA ANALYSIS AT ATMOSPHERIC PRESSURE ${ }^{1}$

\begin{tabular}{|c|c|c|c|}
\hline Catalyst & Form & $\begin{array}{c}\text { Temperature } \\
\text { C }\end{array}$ & $\begin{array}{l}\mathrm{k}, 1 / \mathrm{h} \\
\text { average }\end{array}$ \\
\hline \multirow{3}{*}{ None } & \multirow{3}{*}{$-\cdots$} & 700 & 0.07 \\
\hline & & 750 & 0.14 \\
\hline & & 800 & 0.33 \\
\hline \multirow{6}{*}{ Calcium } & \multirow{3}{*}{$\begin{array}{c}\text { Dry } \\
\text { (Limestone) }\end{array}$} & 700 & 0.09 \\
\hline & & 750 & $0.23-0.59$ \\
\hline & & 800 & $0.47-1.45$ \\
\hline & \multirow{3}{*}{$\underset{\mathrm{Ca}^{++}}{\text {Impregnated }}$} & 700 & 0.26 \\
\hline & & 750 & 0.40 \\
\hline & & 800 & 0.82 \\
\hline \multirow{6}{*}{ Iron } & \multirow{3}{*}{$\begin{array}{c}\text { Dry } \\
\text { (Taconite } \\
\text { Tailings) }\end{array}$} & 700 & 0.07 \\
\hline & & 750 & 0.20 \\
\hline & & 800 & 0.41 \\
\hline & \multirow{3}{*}{$\begin{array}{l}\text { Impregnated } \\
\mathrm{Fe}^{+++}\end{array}$} & 700 & 0.11 \\
\hline & & 750 & 0.20 \\
\hline & & 800 & 0.41 \\
\hline \multirow{8}{*}{ Potassium } & \multirow{3}{*}{$\begin{array}{c}\text { Dry } \\
\left(\mathrm{K}_{2} \mathrm{CO}_{3}\right)\end{array}$} & 700 & 7.33 \\
\hline & & 750 & $4.36-15 \cdot 32$ \\
\hline & & 800 & 27.93 \\
\hline & \multirow{5}{*}{$\begin{array}{l}\text { Impregnated } \\
\text { (Wood Ash } \\
\text { Leachate) }\end{array}$} & 600 & 0.91 \\
\hline & & 650 & 2.82 \\
\hline & & 700 & $0.95-8.55$ \\
\hline & & 750 & $2.60-16.87$ \\
\hline & & 800 & $8.54-25.07$ \\
\hline
\end{tabular}

1 Range indicates data obtained with two different sources of Illinois No. 6 coal. 


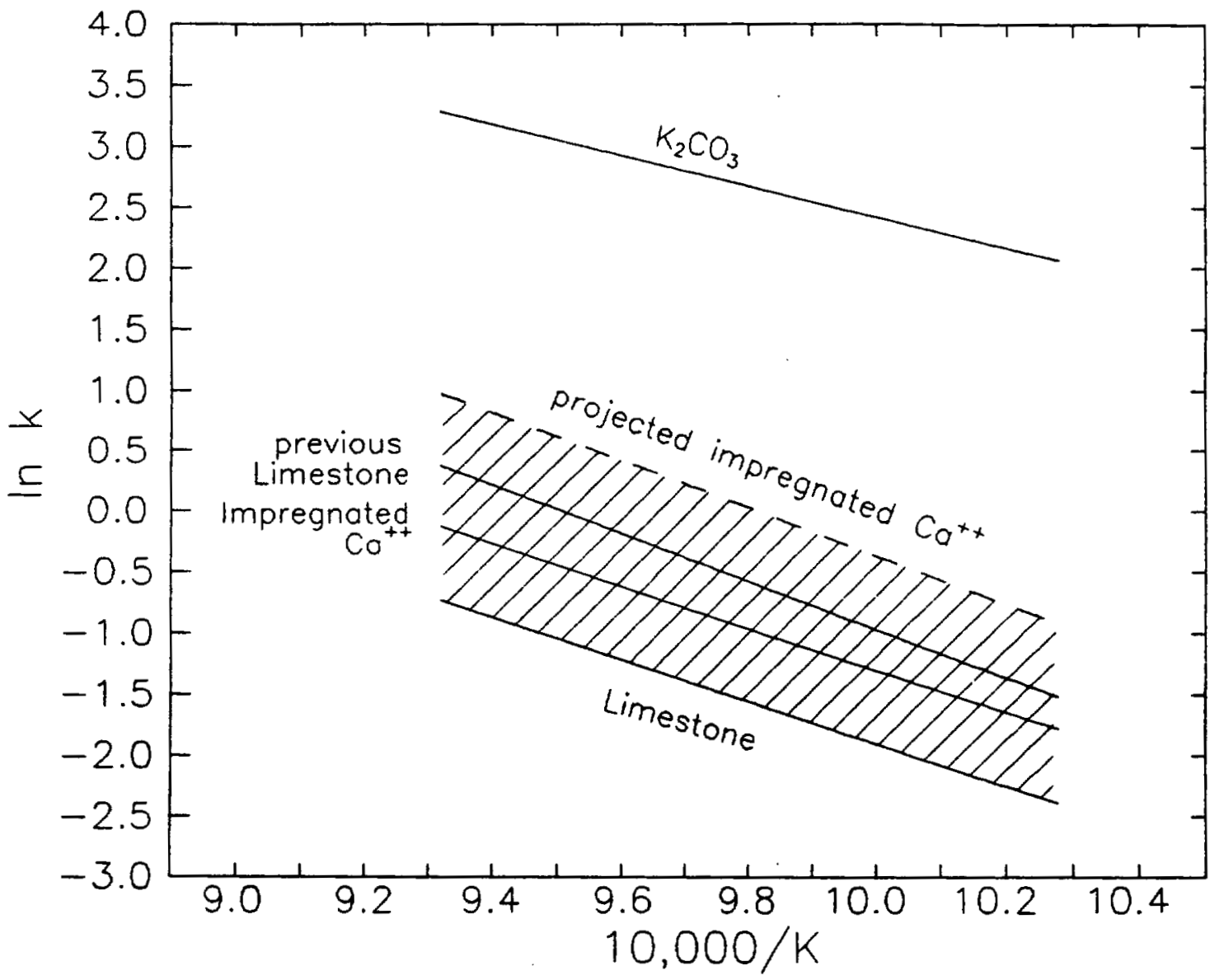

JF0032

Figure 4 TGA REACTIVITY DATA OF ILLINOIS NO. 6 WITH GASIFICATION CATALYSTS AT ATMOSPHERIC PRESSURE

The reactivity of Illinois No. 6 with calcium is best represented as a range. 
For comparison, the reactivity of Illinois $\mathrm{No} .6$ and $\mathrm{K}_{2} \mathrm{CO}_{3}$ was back calculated from the Exxon study data and extrapolated to the lower gasifier temperature used in this study using the TGA reactivity data obtained in this study, as follows:

$$
\begin{gathered}
k=\frac{W_{c}}{\rho_{b} X_{c} V_{B}}=\frac{158,0431 b C / h}{\left(331 b \text { bed } / f t^{3}\right)(0.2461 b \mathrm{C} / \mathrm{lb} \mathrm{Bed})\left(36,873 \mathrm{ft}^{3}\right)}=0.53 \mathrm{~h}^{-1} \\
k_{650^{\circ} \mathrm{C}}=\frac{0.53 \mathrm{~h}^{-1}}{10^{\frac{\mathrm{s} 1 \mathrm{ope}}{\Delta \mathrm{T}}}}=0.25 \mathrm{~h}^{-1}
\end{gathered}
$$

where:

$$
\begin{array}{ll}
\mathrm{k} & =\text { Carbon Reactivity, } \mathrm{h}^{-1} \\
\mathrm{~W}_{\mathrm{c}} & =\text { Weight of Carbon Reacted, } \mathrm{lb} / \mathrm{h} \\
\rho \mathrm{b} & =\text { Bed Density, } \mathrm{lb} / \mathrm{ft}^{3} \\
\mathrm{X}_{\mathrm{c}} & =\text { Carbon Weight Fraction in Bed } \\
\mathrm{V}_{\mathrm{B}} & =\text { Reactor Bed Volume, } \mathrm{ft}^{3} \\
\text { Slope } & =0.0078 \\
\Delta T & =42^{\circ} \mathrm{C}
\end{array}
$$

The reactivities determined by TGA are compared with those assumed in the system studies and the reactivity back calculated from the Exxon study in Table 3.

Table 3 COMPARISON OF SYSTEM STUDY AND TGA REACTIVITIES

\begin{tabular}{|l|c|c|}
\hline Reactivity Data Source & $\begin{array}{c}\text { Case 1 } \\
\mathrm{K}_{2} \mathrm{CO}_{3} \text { at } 650^{\circ} \mathrm{C}\end{array}$ & $\begin{array}{c}\text { Case } 2 \text { \& } 3 \\
\mathrm{CaCO}_{3} \text { at } 650^{\circ} \mathrm{C}\end{array}$ \\
\hline TGA Experimental (1 atm) & 2.82 & $\begin{array}{c}0.05-0.129 \text { (dry) } \\
0.134 \text { (impregnated) }\end{array}$ \\
\hline System Study (750 psig) & 0.255 & 0.103 \\
\hline
\end{tabular}

The TGA reactivity value for potassium catalyzed Illinois No. 6 is an order of magnitude greater than the reactivity used in Case 1 , indicating that a conservative reactivity was chosen for this case, considering the fact that the system study is at 750 psig pressure and that reactivity generally improves with pressure. The calcium reactivity assumed for the system study is $80 \%$ of TGA data using dry calcium at atmospheric pressure. This could be underestimating reactivity which is expected to improve with pressure. The reactivity for impregnated calcium is about $10 \%$ higher. Use of lower rank coals is expected to result in significantly higher reactivities, as with higher operating pressure. 


\subsubsection{INTEGRATED BENCH-SCALE GASIFIER TESTING REACTIVITY MEASUREMENTS}

Bench-scale reactor testing of whole coal, rather than coal char tested in the TGA, approaches the performance of larger scale gasifiers. The Integrated Bench-Scale Gasifier (IBG) tested at UND/EERC is shown in Figure 5. Based on the relatively low reactivities obtained with calcium and taconite, it was decided to continue this phase of experimental testing using Illinois No.6 coal impregnated with pctassium and simulated recycle from the fuel cell exhaust. A schematic of the IBG is illustrated in Figure 6 .

This batch fluid bed gasifier injects $\sim 70$ grams of coal into a preheated fluidized bed. To initiate a run, the system is brought up to temperature while steam and nitrogen are added at flow rates approximating the predetermined fluidization velocity. When the system reaches $-100^{\circ} \mathrm{C}$ below the target temperature, the steam is turned off and the char collection pots and condensate pots are drained. Once the target temperature is reached and allowed to stabilized for $-1 / 2$ hour, the coal feed in the feed hopper is sealed and purged with nitrogen. The feed gas is switched to a nitrogen/hydrogen/steam mixture simulating the case study composition while the system is pressurized. When operating pressure has been reached, the feed hopper valve opens and the coal feed is forced into the gasifier by a high pressure nitrogen purge.

Reaction progress is monitored by charting the relative concentrations of $\mathrm{CO}_{2}, \mathrm{CO}$ and $\mathrm{CH}_{4}$ in the product gas versus time. The relative compositions are determined by a Fourier Transform InfraRed (FTIR) analyzer in 20 second sampling intervals. This data is also used to determine reactivity measurements. An example of the FTIR spectra for one run is shown in Figure 7. The double ridge shows the $\mathrm{CO}$ and $\mathrm{CO}_{2}$ absorbance spectra; the smaller ridge to their left is the $\mathrm{CH}_{4}$ spectra. The ripples to the far right indicate water, while those on the far left indicate undefined heavier organics. Gas chromatograph (GC) analyses are also performed on gas bag samples.

When the carbon consumption is $-90 \%$ complete (indicated by the FTIR), the run is terminated. The discharge valve is opened and the reactor contents are dumped into the char pot. The solids in the char pot are dried overnight in a nitrogen-blanketed oven and used for proximate, ultimate and XRFA analyses and leaching tests.

Reactivity is determined using the FTIR analysis; this process is illustrated in Figure 8. The $\mathrm{CO}_{2}$ absorbance data is more dominant than either the $\mathrm{CH}_{4}$ or $\mathrm{CO}$ absorbance data, and therefore was used to measure the rate of carbon consumption. The integral of the $\mathrm{CO}_{2}$ absorption curve is an indication of the amount of unreacted carbon; the maximum slope defines the carbon consumption. The intercept of this line is offset indicating the time lag for the cold, injected coal feed to reach reaction temperature. Two rescaled versions of this integral line representing the fixed carbon (FC) and the total carbon (TC) loss are also shown. When the integral approximates a well-behaved exponential function, a straight line (designated "reactivity") is drawn with an empirical slope and intercept adjusted to fit the maximum slope of each of the three curves. The slope of this line is reported as the reactivity. This method for obtaining reactivity is referred to as the "Tangent Slope Method". 


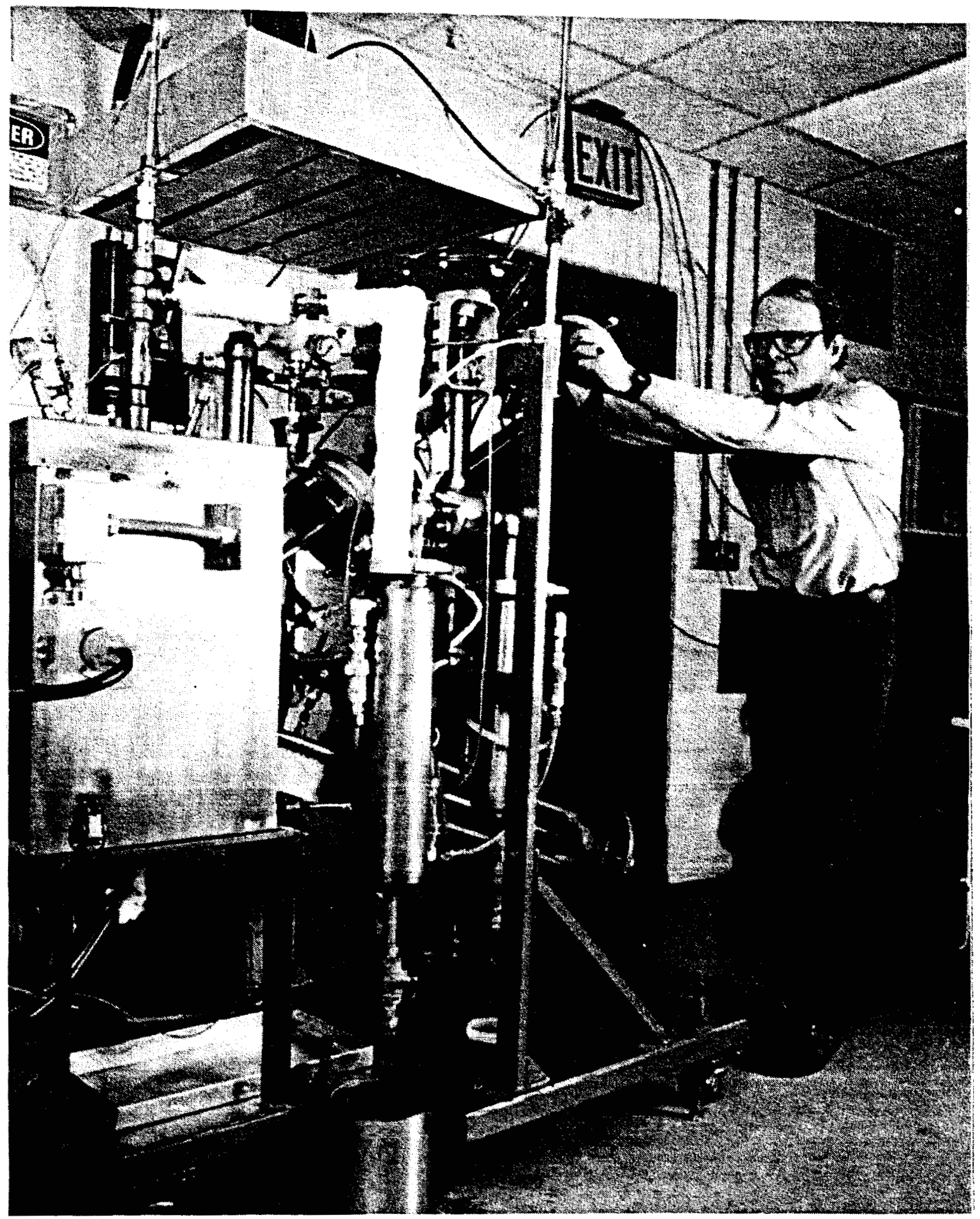

Figure 5 INTEGRATED BENCH SCALE GASIFIER 


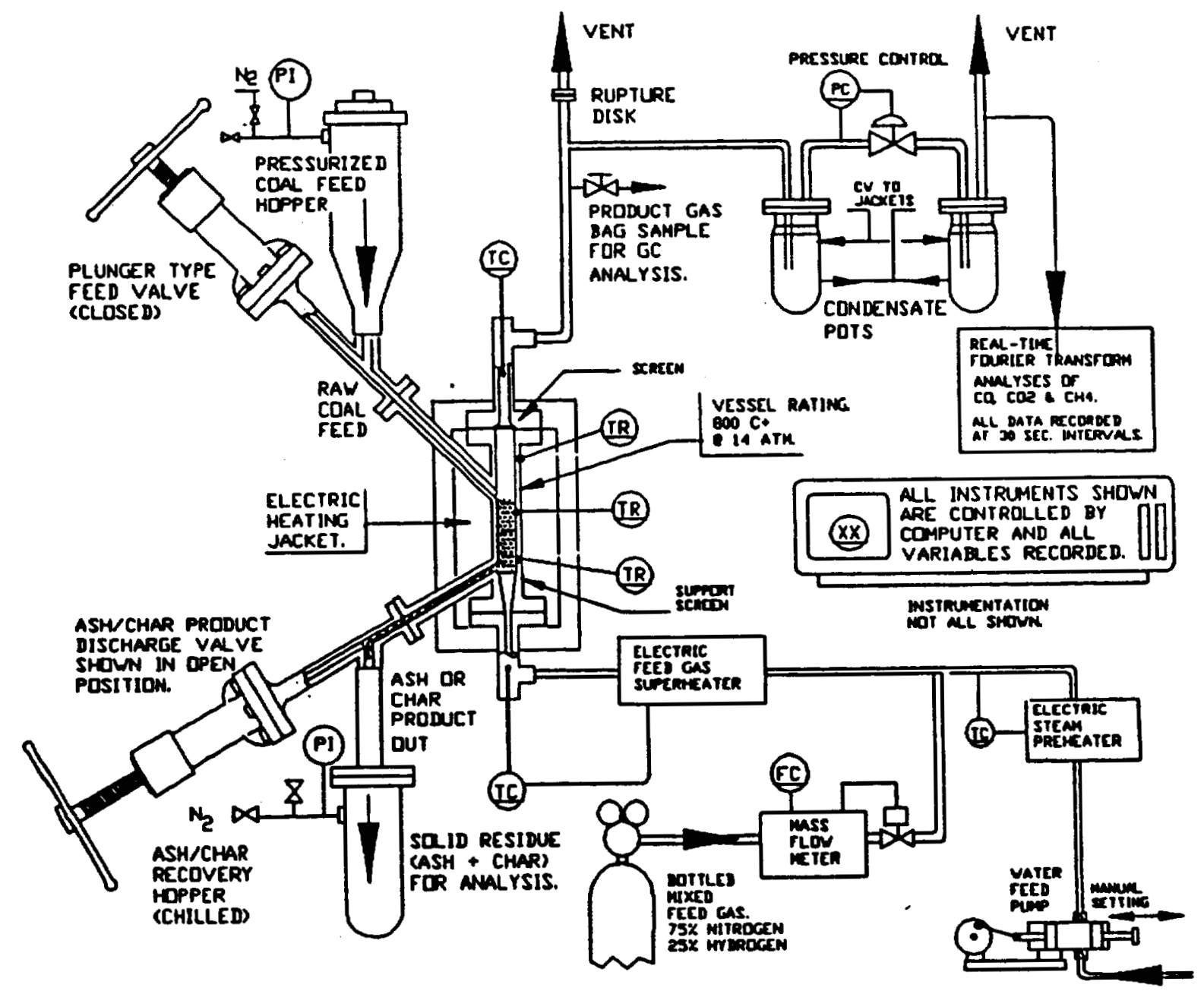

Figure 6 INTEGRATED BENCH-SCALE GASIFIER SCHEMATIC 


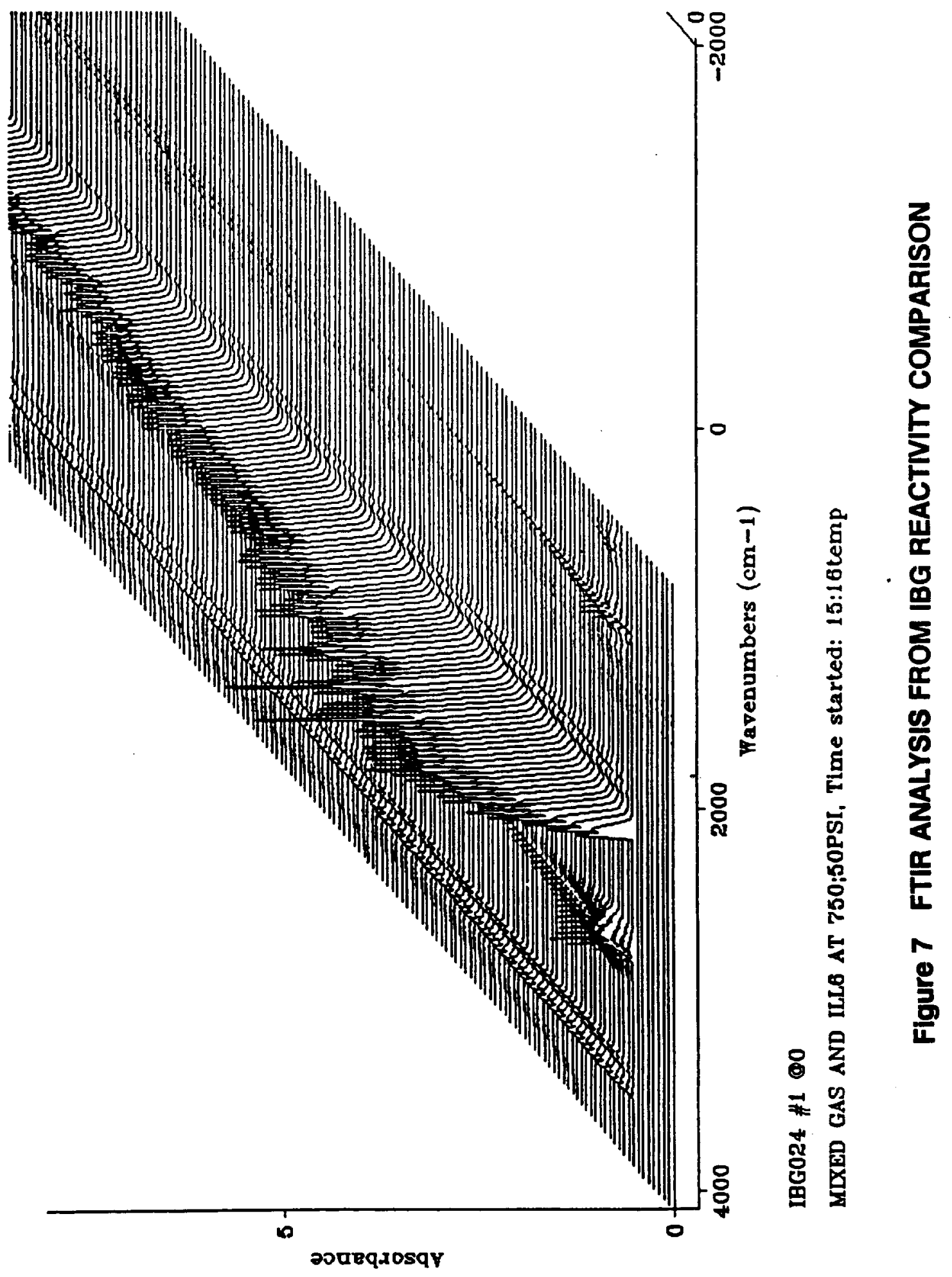




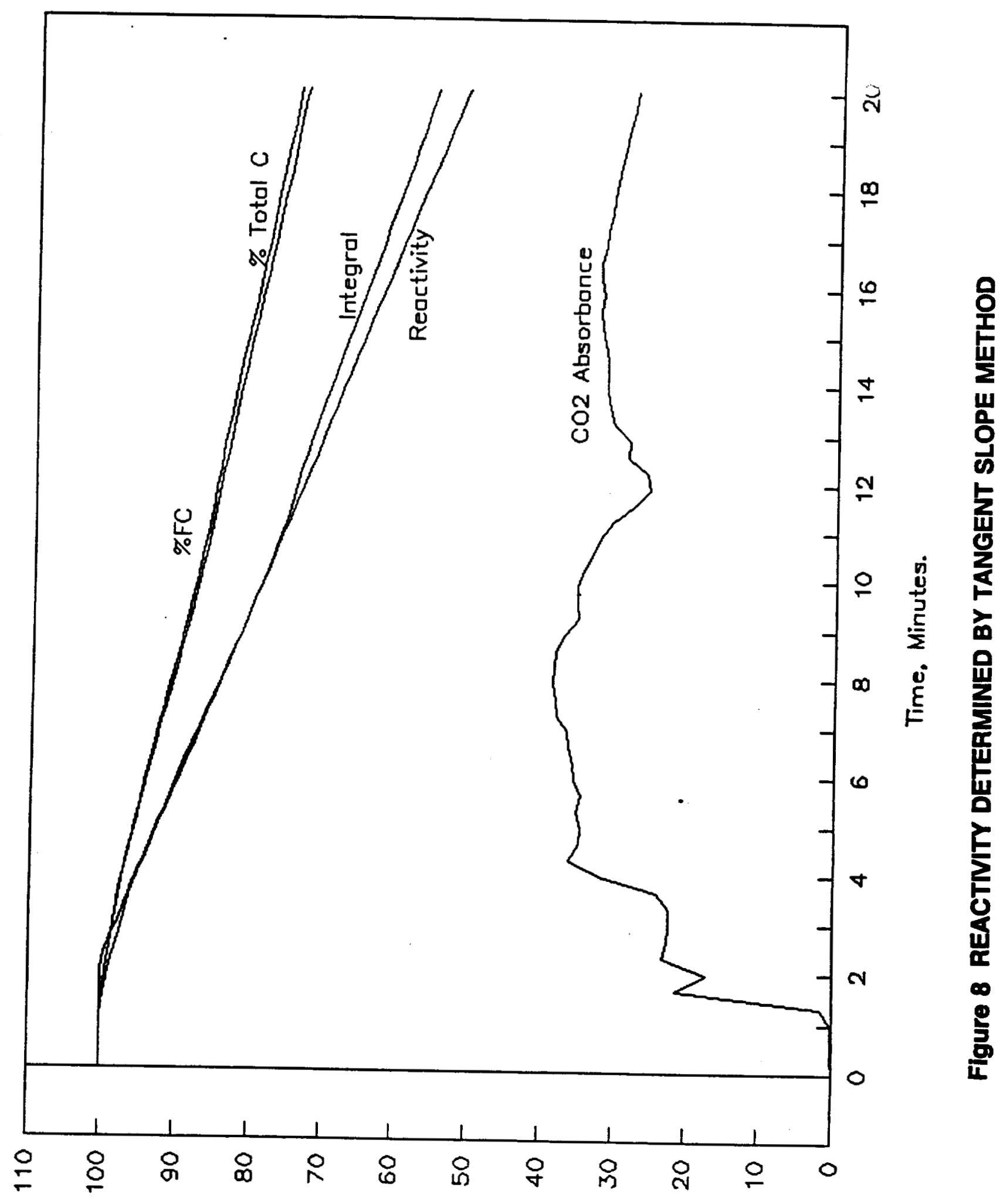

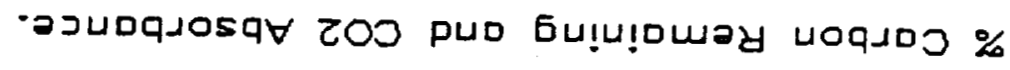


This method is valid to the extent that the curve approached a consistent zero to second order exponential. However, due to erratic gas velocity, inconsistent sample gas flow to the FTIR, and/or incomplete fluidization, the effective reactivity may fluctuate during a run. An example of this is Run IBG-029, shown in Figure 9. The $\mathrm{CO}_{2}$ absorbance trace is a series of $\sim 4$ peaks, suggesting that the reaction stopped and started several times. When integrated and matched to an exponential function by a least-squares fitting procedure, a curve resulted with a mathematical form of:

$$
Y=e^{-\frac{\left(t-t_{0}\right) k}{60}}
$$

where the initial slope, $k$, would be tangent to the early point of inflection in a "wellbehaved" second order curve. The constant, $t_{0}$, is a delay factor indicating the time required for the cold feed to reach reaction temperature. The slope is multiplied by 60 to convert into the conventional reactivity units of $h^{-1}$. This reactivity should be similar to the result that would have been obtained by the tangent slope method. This method of calculating reactivity is defined as the "Whole Exponential Curve Fitting Method".

An initial baseline IBG run was performed using washed Illinois No. 6 coal and subsequent runs were performed using a $15 \mathrm{wt}$ \% potassium-impregnated llinois No. 6 coal feed. Analysis of the coal feeds and ash are compared with the EPRI TAG values in Table 4. The proximate and ultimate analysis of the "as received" washed coal available for testing at EERC compares reasonably well with the average analysis for EPRI TAG Representative East Central Illinois No. 6, although the coal tested is somewhat lower in ash (12.3 wt.\% vs. $16.0 \mathrm{wt} . \%)$.

Analysis of the potassium impregnated Illinois No. 6 only indicates that the potassium addition and subsequent drying skews the data, with potassium contributing to the volatiles and ash figures. The ash analysis indicates an increase in potassium oxide for the catalyzed coal as expected. The increased sulfur in the ash, if accurate, may be an indication of a reaction with potassium and sulfur compounds in the coal, and stabilization in the ash.

A total of ten IBG runs were conducted at temperatures ranging from $650^{\circ} \mathrm{C}$ to $750^{\circ} \mathrm{C}$, and at pressures extending from atmospheric to $150 \mathrm{psig}$. The reactivities obtained in the batch gasification testing are listed in Table 5. One run was performed using raw illinois No. $6 \mathrm{coal}$ without catalyst impregnation, $\left(700^{\circ} \mathrm{C}\right.$, atmospheric pressure) and agglomeration of the coal resulted in poor fluidization and therefore poor reactivity measurement. The variation of reactivity of potassium-impregnated coal with temperature is as expected for determinations using the same method. The uncertainty in comparison of such data by slightly different methods is apparent. Ignoring the data for IBG-029 $\left(650^{\circ} \mathrm{C}, 50 \mathrm{psig}\right)$ the data fits a consistent and expected pattern: reactivity increases with temperature and pressure. 


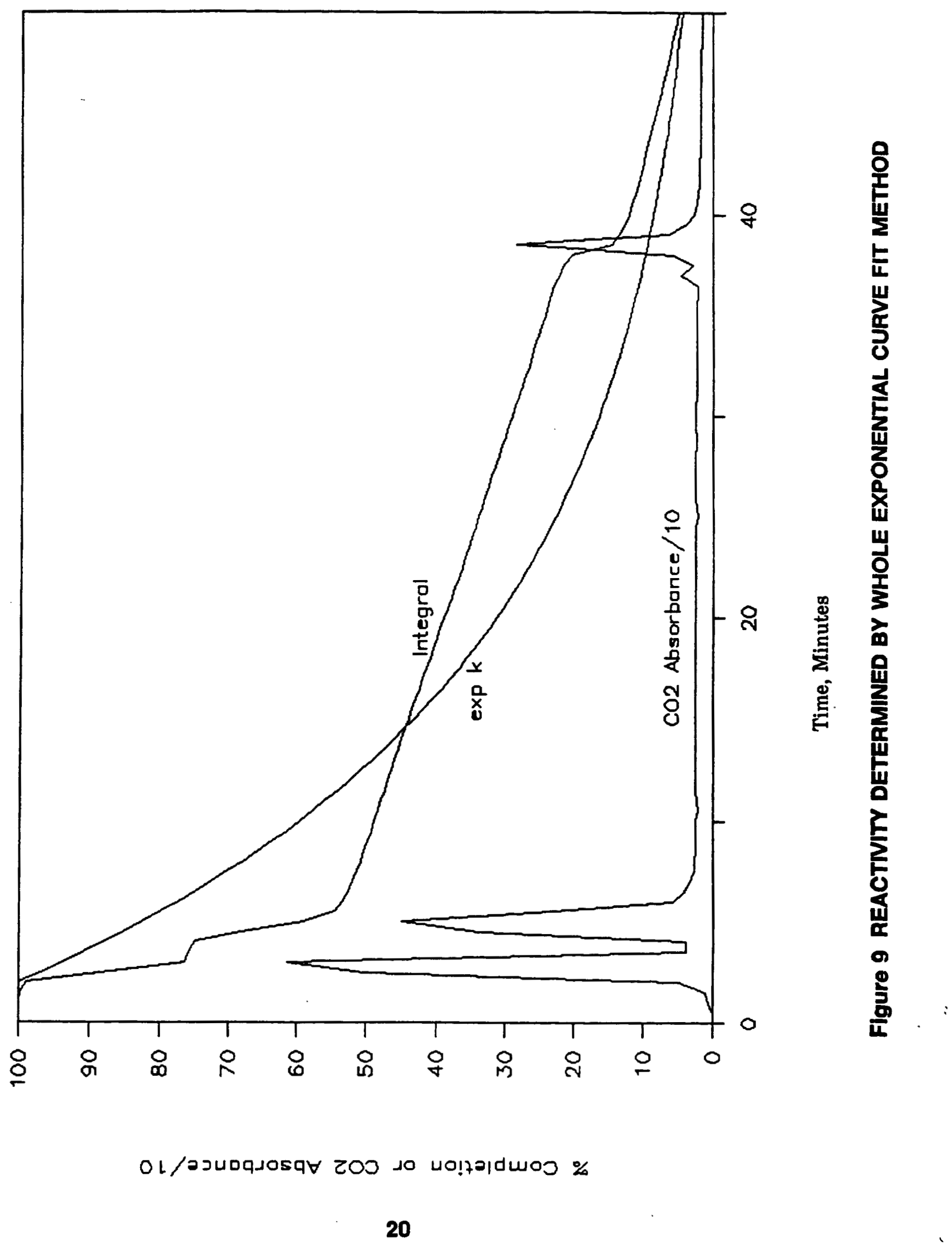




\section{Table 4 PROXIMATE AND ULTIMATE ANALYSIS OF WASHED AND POTASSIUM-IMPREGNATED ILLINOIS NO. 6 COAL}

\begin{tabular}{|c|c|c|c|}
\hline $\begin{array}{l}\text { Proximate Analysis, } \\
\text { wt: }\end{array}$ & EPRI TAG & 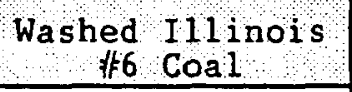 & $\begin{array}{l}\text { Potassium-Inpregnated } \\
\text { Illinois \#6 Coal }\end{array}$ \\
\hline Moisture & 12.0 & 13.8 & 4.6 \\
\hline Fixed Carbon & 39.0 & 42.4 & 28.6 \\
\hline Volatiles & 33.0 & 31.5 & 44.5 \\
\hline Ash & 16.0 & 12.3 & 22.3 \\
\hline Total & 100.0 & 100.0 & 100.0 \\
\hline $\begin{array}{l}\text { Ultimate Analysis, } \\
\text { wt\% }\end{array}$ & EPRI TAG & $\begin{array}{c}\text { Raw Illinois } \# 6 \\
\text { Coal }\end{array}$ & $\begin{array}{l}\text { Potassium-Impregnated } \\
\text { I1linois } \# 6 \text { Coal }\end{array}$ \\
\hline Moisture & 12.0 & 13.8 & 4.6 \\
\hline $\mathrm{H}$ & 3.7 & 3.5 & 3.8 \\
\hline $\mathrm{C}$ & 57.5 & 56.5 & 58.4 \\
\hline $\mathbf{N}$ & 0.9 & 1.0 & 1.1 \\
\hline $\mathbf{S}$ & 4.0 & 3.1 & 2.4 \\
\hline 0 & 5.8 & 9.8 & 7.4 \\
\hline Ash & 16.0 & 12.3 & 22.3 \\
\hline $\mathrm{Cl}$ & 0.1 & --- & -- \\
\hline Total & 100.0 & 100.0 & 100.0 \\
\hline Ash Aralysis, wt $z$ & EPRI TAG & $\begin{array}{l}\text { Washed Illinois } \\
\text { Hoal }\end{array}$ & $\begin{array}{l}\text { Potassi um-Impregnated } \\
\text { Illinois } 6 \text { Coal }\end{array}$ \\
\hline Silica, $\mathrm{SiO}_{2}$ & 45.0 & 48.93 & 27.29 \\
\hline Alumina, $\mathrm{Al}_{2} \mathrm{O}_{2}$ & 18.0 & 18.29 & 21.55 \\
\hline Ferric Oxide, $\mathrm{Fe}_{2} \mathrm{O}_{3}$ & 20.0 & 13.92 & 5.17 \\
\hline Titanic Oxide, $\mathrm{TiO}_{2}$ & 1.0 & $\ldots$ & $\cdots$ \\
\hline Calcium Oxide, $\mathrm{CaO}$ & 7.0 & 6.93 & 1.38 \\
\hline Magnesia, MgO & 1.0 & 1.39 & 0.82 \\
\hline Sodium Oxide, $\mathrm{Na}_{2} \mathrm{O}$ & 0.6 & 1.33 & 0.31 \\
\hline Potassium Oxide, $\mathrm{K}_{2} \mathrm{O}$ & 1.9 & 1.89 & 26.24 \\
\hline Sulfur Trioxide $\mathrm{SO}_{3}$ & 3.5 & 6.18 & 17.20 \\
\hline $\begin{array}{l}\text { Phosphorous } \\
\text { Pentoxide, } \mathrm{P}_{2} \mathrm{O}_{5}\end{array}$ & 0.2 & $\cdots$ & -- \\
\hline Undetermined & 1.8 & 1.14 & 0.03 \\
\hline & 100.0 & 100.00 & 100.00 \\
\hline
\end{tabular}

${ }^{1}$ EPRI Technical Assessment Guide P-4463-SR Vol 1, page 2-10, Dec. 1986. 
The TGA data of potassium-impregnated Illinois No. 6 obtained in the first phase of experimental testing is included in Table 5 for comparison to bench-scale testing of whole coal. As stated in the previous section, the TGA experiments measure the reactivity of a first order steam-char, reaction and therefore are higher than the batch gasifier reactivities at similar conditions. However, activation energies as determined by the slope of Arrenius plot are comparable for the TGA and IBG data shown in Figure 10. As a result, the reactivity of the IBG data and the TGA data show similar increases with temperature, especially with the lower pressure IBG data. The higher pressure IBG data was somewhat unsteady due to fluidization problems at high pressure, which may explain the different activation energy at higher pressure. The data obtained indicates improvement of reactivity with pressure, whereby bench-scale data at 150 psig approaches TGA data at $1 \mathrm{~atm}$, as indicated in Figure 10. If this trend continues at higher pressures then reactivity at the system condition of 750 psig would exceed TGA reactivity by a significant margin.

Table 5 REACTIVITIES OF POTASSIUM-IMPREGNATED ILLINOIS NO. 6 COAL $k,(1 / h)$

\begin{tabular}{|c|c|c|c|c|}
\hline $\begin{array}{c}\text { Temperature, } \\
\mathrm{C}\end{array}$ & \multicolumn{3}{|c|}{ Pressure, psig } & TGA \\
\cline { 2 - 5 } & Atmospheric & 50 & 150 & Atmospheric \\
\hline 650 & $\mathrm{NP}^{\star}$ & $3.87^{\star \star \star}$ & $4.03^{\star \star \star}$ & 2.82 \\
\hline 700 & $0.15^{\star \star}$ & $0.60-1.80$ & $\ldots \ldots$ & 8.55 \\
\hline 750 & $\ldots \ldots$ & 2.58 & $11.38^{\star \star \star}$ & 16.87 \\
\hline
\end{tabular}

a TGA results using $0.12 \mathrm{eg} \mathrm{mol} \mathrm{K} / \mathrm{mol} \mathrm{FC}$.

-. Reactivity determination not possible.

-* Raw Illinois No 6 coal used (no catalyst), $k$ determined by manually recorded $\mathrm{CO}$ content in the product gas.

Reactivity determined by exponential curve fitting method. Unless otherwise noted, all other reactivities determined by tangent line method.

The IBG product gas composition (dry basis) at $750^{\circ} \mathrm{C} / 50$ psig (Run No. IBG-024) was compared to the predicted equilibrium values. These results, listed in Table 6 , verify that the system was very near equilibrium.

Table 6 IBG PRODUCT GAS COMPOSITION AND EQUILIBRIUM COMPOSITION

\begin{tabular}{|c|c|c|}
\hline \multirow{2}{*}{$\begin{array}{c}\text { Stream } \\
\text { Components }\end{array}$} & \multicolumn{2}{|c|}{ Composition, $\%$} \\
\cline { 2 - 3 } & IBG -024 Product Stream & Equilibrium Composition \\
\hline $\mathrm{H}_{2}$ & 31.5 & 32.0 \\
\hline $\mathrm{CO}_{2}$ & 4.0 & 3.6 \\
\hline $\mathrm{CO}$ & 0.7 & 1.4 \\
\hline $\mathrm{CH}_{4}$ & 0.4 & 0.04 \\
\hline $\mathrm{N}_{2}$ & 63.3 & 62.9 \\
\hline
\end{tabular}




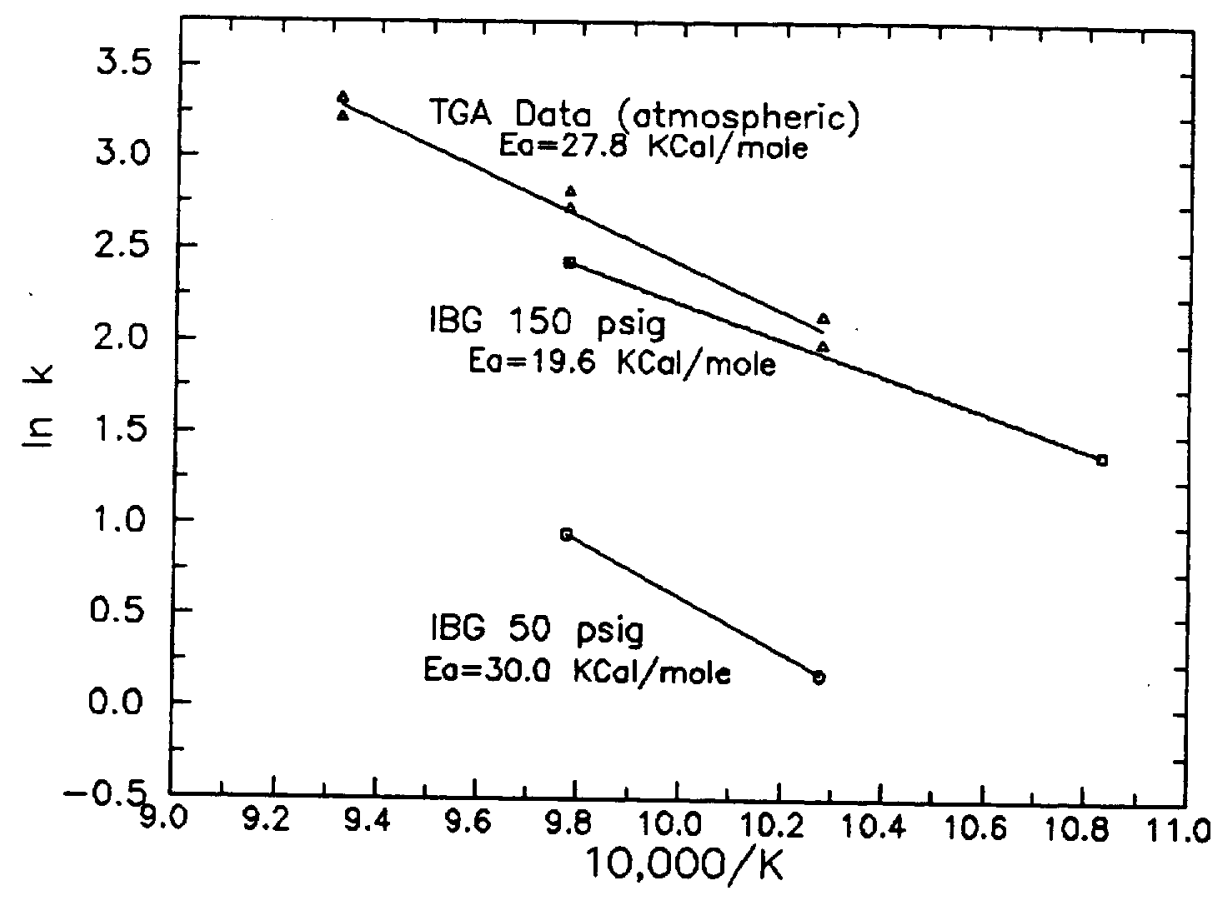

$\sqrt{-0031}$

Figure 10 POTASSIUM CATALYZED ILLINOIS NO. 6 BENCH-SCALE GASIFICATION AND TGA REACTIVITIES

Bench-scale reactivity at low pressure is below TGA reactivity at $1 \mathrm{~atm}$, but increases with increasing pressure. 


\section{Potassium Recovery}

The advantage of the highly reactive potassium as a gasification catalyst is offset somewhat by the recovery plant needed to recycle this expensive catalyst. A measure of the potassium recovery by water leaching was obtained to quantify the effectiveness of this simple technique.

In order to obtain potassium recovery from the gasifier, the IBG ash samples were leached in water, dried and weighed, and submitted for Loss on Ignition (LOI) and XRFA analyses. Potassium recovery based on the total potassium present in the residual ash/char sample is listed in Table 7. Ash plugs, which accumulated in the top screen of the reactor when runs were performed in succession, were sampled. These plugs were analyzed separately and are indicated in the table by $21 / 23,24 / 25$, and $27 / 29$. The data indicates that potassium recovery of $39-78 \%$ was achieved by water leaching alone. This result appears to support previous research by Exxon ${ }^{(2)}$ which concluded that $90 \%$ recovery can be achieved using lime and aqueous $\mathrm{Ca}(\mathrm{OH})_{2}$ to enhance recovery.

Table 7 POTASSIUM RECOVERY FROM LEACHED GASIFIER RESIDUE

\begin{tabular}{|c|c|c|c|c|}
\hline \multirow[t]{3}{*}{ Temperature, $\mathrm{C}$} & \multicolumn{4}{|c|}{ Pressure, psig } \\
\hline & \multicolumn{2}{|c|}{50} & \multicolumn{2}{|c|}{150} \\
\hline & Run Number & $\begin{array}{l}\text { Potassium, } \\
\text { Recovery, } 7\end{array}$ & Run Number & $\begin{array}{l}\text { Potassium } \\
\text { Recovery, } \mathbf{z}\end{array}$ \\
\hline 650 & $\begin{array}{c}\text { IBG }-029 \\
27 / 29 \\
\end{array}$ & $\begin{array}{l}38.94 \\
77.86\end{array}$ & IBG-028 & $57.58 \%$ \\
\hline 700 & $\begin{array}{c}\text { IBG-021 } \\
\text { IBG-022 } \\
\text { IBG-023 } \\
21 / 23 \\
\end{array}$ & $\begin{array}{l}70.48 \\
64.15 \\
65.50 \\
66.97 \\
\end{array}$ & -- & -- \\
\hline 750 & $\begin{array}{c}\text { IBG-024 } \\
\text { IBG-025 } \\
24 / 25\end{array}$ & $\begin{array}{l}70.0 \\
68.7 \\
64.1\end{array}$ & IBG -027 & 68.47 \\
\hline
\end{tabular}




\subsection{CONCLUSIONS}

The integration of catalytic gasification with carbonate fuel cells can potentially improve the performance and efficiency of future power generation plants. The low temperature catalytic gasification of coal offers the potential of more efficient gasification at a temperature more compatible with carbonate fuel cells and integration with fuel cell exhaust streams. Low temperature catalytic gasification produces a methane rich fuel gas which results in more efficient fuel cell operation by utilizing the internal reforming capability of carbonate fuel cells. This program evaluated the potential of integrating carbonate fuel cells with the gasification process to obtain a more efficient system utilizing Illinois No. 6 as a representative coal. Three case studies were investigated:

- Case 1 - a recoverable gasification catalyst with cold cleanup.

- Case 2 - a disposable gasification catalyst with cold cleanup.

- Case 3 - a disposable gasification catalyst with hot cleanup.

Efficiencies of $51.7 \%, 50.6 \%$ and $53.5 \%$, respectively, all on a higher heating value basis, were obtained. Hot gas cleanup was found to improve efficiency by 2.9 percentage points. In addition, moisturization of the fuel gas is not required with hot gas cleanup as with cold gas cleanup because moisture is not condensed from the fuel gas before desulfurization. Based on the improvement achievable with hot gas cleanup, it is projected that a potassium catalyzed system with hot gas cleanup can achieve efficiencies approaching $55 \%$.

Comparing integrated catalytic gasification carbonate fuel cells to conventional gasification carbonate fuel cells results in a 5 percentage point advantage for integrated gasification carbonate fuel cells (55\% versus $50 \% \mathrm{HHV}$ ). Compared to competing technologies, a 15 percentage point advantage over IGCC is estimated (55\% versus $40.5 \%$ ), and a 23 percentage point advantage over PC and AFBC was determined. The integrated gasification carbonate fuel cell has the potential for eliminating the oxygen plant, which is the biggest power consumer in a conventional plant and a significant capital cost. The potential improvement in overall efficiency provides a strong incentive to explore this possibility further.

Experimental testing of selected gasification catalysts was conducted to verify the catalytic activity assumed in the system studies. Preliminary testing was conducted by TGA at atmospheric pressure. The catalysts tested were potassium carbonate, limestone, and taconite, a naturally occurring iron containing mineral. The role of the taconite is to capture sulfur at the lower operating temperature of the catalytic gasifier, where the reactivity of limestone for sulfur capture is somewhat limited. It was recognized that TGA data at atmospheric pressure is only an approximation of reactivity which can be used to assess the relative reactivities of the catalysts of interest. As expected, potassium carbonate exhibited the highest reactivities among the catalysts tested by TGA. These tests were followed by bench-scale testing at pressures up to $150 \mathrm{psig}$, utilizing a recently built fluid bed batch gasifier at EERC. This test unit provides more realistic test conditions approaching large scale commercial gasifiers. Although some operational problems were encountered, tests conducted with potassium catalyzed coal were encouraging. 
Conclusions relating to the experimental catalytic gasification investigation are summarized below.

- TGA testing of Illinois $\mathrm{No} .6$ at atmospheric pressure indicates that $\mathrm{K}_{2} \mathrm{CO}_{3}$ catalyzed reactivity is an order of magnitude higher compared to calcium tested in this program. Previous testing of a different Illinois No. 6 by EERC with dry calcium resulted in approximately twice the reactivity obtained in this program, indicating that there is significant variability with coal sources even within the same rank.

- Based on TGA testing at atmospheric pressure, impregnated calcium improves reactivity compared to dry calcium by a factor of 2-3 for the coal and temperature range tested by improving the distribution of catalyst within the coal structure. Overall improvement in reactivity compared to uncatalyzed llinois No. 6 approached a factor of 4 .

- Fixed bed reactor testing by other researchers ${ }^{(7,8)}$ utilizing calcium catalyzed 1 llinois No. 6 achieved an improvement in reactivity by a factor of 10-15 compared to uncatalyzed coal. This indicates that reactivity of the whole coal could be higher than the reactivity of the char tested by TGA.

- Based on TGA data at atmospheric pressure, the use of taconite alone does not improve reactivity significantly. Its anticipated role was for sulfur capture with hot gas cleanup.

- Batch fluid bed gasifier testing at pressure up to $150 \mathrm{psig}$ indicates that the reactivity of $\mathrm{K}_{2} \mathrm{CO}_{3}$ catalyzed Illinois No. 6 was conservatively estimated in the system study summarized in Appendix A, and that reactivity improves with increasing pressure.

Additional tests with impregnated calcium at elevated pressures are required at bench-scale or larger to determine the range of reactivities possible. Improved calcium reactivities by impregnation and operation at higher pressures are expected to improve the economic feasibility of using disposable catalysts. Trade-offs against potassium should be made when reactivities for calcium at realistic gasifier conditions are obtained. In addition, testing and development of catalytic gasification for fuel cell applications should be expanded to include sub-bituminous and low rank coals to assess potential economic advantages. 


\section{REFERENCES}

1. Farooque, M., G. Steinfeld, G. McCleary, S. Kremenik, "Assessment of Coal Gasification/Carbonate Fuel Cell Power Plants," Topical Report, Contract No. DEAC21-87MC23274 (June 1990).

2. Exxon Research and Engineering Company, Baytown, Texas,"Exxon Catalytic Coal Gasificetion Process Predevelopment Program," Final Project Report, Contract No. EX-76-C-01-2369 (Dec. 1978).

3. Gmeindl F.D., R.A. Geirsbrecht, K.R. Craig, S. Kasper, Morgantown Energy Technology Center; V.N. Shah, EG\&G Washington Analytical Services, "New Directions in Molten Carbonate Fuel Cell Systems," Proceedings of the Ninth Annual Gasification and Gas Stream Cleanup Systems Contractors Review Meeting, Morgantown, WV June 1989. Report No. DOE/METC-89/6107, Vol 2 (Order No. DE89011707).

4. United Technologies Corporation, "The Study of Integrated Coal Gasifier Molten Carbonate Fuel Cell Systems," Final Technical Report prepared for the Jet Propulsion Laboratory (July 10, 1983).

5. Energy Research Corporation, "Design of Gasifiers to Optimize Fuel Cell Systems," Topical Report, Contract No. DE-AC21-90MC27227, 1992.

6. Pullen, J.R.; "Catalytic Coal Gasification," Report No. ICTIS/TR26, IEA Coal Research, London (June 1984).

7. Linares-Solano, A; Salinas-Martinez de Lecea, C.; Cazoria-Amoros, D.; Joly, J.P. "An approach to the mechanism of the $\mathrm{CO}_{2}$-carbon gasification reaction catalyzed by calcium." In: Fundamental issues in control of carbon gasification reactivity (NATO ASI Series E: Applied Sciences vol. 192). Lahaye J., Ehrburger (eds) NATO Advanced Workshop on Fundamental Issues in Control of Carbon Gasification Reactivity. Cadarache (France) 30 Jul - 3 Aug 1990.

8. Ohtsuka, Y.; Asami, K.; "In situ sulfur capture during the calcium-catalyzed gasification of Illinois No. 6 coal." In: Processing and utilization of high-sulfur coals IV (Coal science and technology vol. 18).Dugan, P.R., Quigley, D.R., Attia, Y.A. (eds) International Conference on Processing and utilization of High-Sulfur Coals. Idaho Falls, ID (USA) 26-30 Aug 1991.

9. Sondreal, E., W. Wilson, R. Timpe, S. Cisney, W. Hauserman, "Recommendations for Disposable Gasification Catalysts to Optimize Integrated Gasifier/Fuel Cell Systems," submitted to Energy Research Corporation, January, 1991. 


\section{REPORTS \& PAPERS GENERATED IN THIS PROGRAM}

\section{Conferences:}

Steinfeld, G., W.B. Hauserman, A. Lee, S.J. Meyers; "Design of Gasifiers to Optimize Fuel Cells," Contractor's Review Meeting on Gasification and Gas Stream Cleanup Systems Proceedings, DOE/METC -91/6123 Vol I, August, 1991.

Steinfeld, G., J.Fruchtman, W.B. Hauserman, A. Lee, S.J. Meyers; "Gasifiers Optimized for Fuel Cell Systems," Twelfth Annual Gasification and Gas Stream Cleanup Systems Contractor's Review Meeting, DOE/METC -92/6128 Vol I, September, 1992.

Steinfeld, G., W.B. Hauserman, S.J. Meyers; "Integration of Carbonate Fuel Cells with Advanced Gasification Systems," Abstract for 1992 Fuel Cell Seminar, Tucson, Arizona, Nov. 29-Dec. 2, 1992.

Steinfeld, G., J. Fruchtman; "integration of Carbonate Fuel Cells with Advanced Gasification Systems," 1992 Fuel Cell Seminar Poster Session, Tucson, Arizona, Nov. 29Dec. 2, 1992.

Steinfeld, G., W.B. Hauserman, W.G. Willson; "Advanced Power System Featuring a Closely Coupled Catalytic Gasification Carbonate Fuel Cell Plant," Presented at the Seventeenth Biennial Low-Rank Fuels Symposium, May 10-13, 1993.

\section{Topical Reports:}

Steinfeld, G.; "Design of Gasifiers to Optimize Fuel Cell Systems," Topical Report, February, 1992, Submitted by Energy Research Corporation to DOE/METC Contract No. DE-AC21-90MC27227.

\section{Quarterly Reports:}

Steinfeld, G.; "Design of Gasifiers to Optimize Fuel Cell Systems," Quarterly Report No. 1 (10/1/90 - 12/31/90), 1991.

Steinfeld, G.; "Design of Gasifiers to Optimize Fuel Cell Systems," Quarterly Report No. $2(01 / 1 / 91-03 / 31 / 91), 1991$.

Steinfeld, G.; "Design of Gasifiers to Optimize Fuel Cell Systems," Quarterly Report No. $3(04 / 1 / 91$ - 06/30/91), 1991.

Steinfeld, G.; "Design of Gasifiers to Optimize Fuel Cell Systems," Quarterly Report No. $4(07 / 1 / 91-09 / 30 / 91), 1992$

Steinfeld, G.; "Design of Gasifiers to Optimize Fuel Cell Systems," Quarterly Report No. $5(10 / 1 / 91-12 / 31 / 91), 1992$. 
ENERGY RESEARCH CORPORATION

Steinfeld, G.; "Design of Gasifiers to Optimize Fuel Cell Systems," Quarterly Report No. 6 (01/1/92 - 03/31/92), 1992.

Steinfeld, G.; "Design of Gasifiers to Optimize Fuel Cell Systems," Quarterly Report No. 7 (04/1/92 - 06/30/92), 1992.

Steinfeld, G.; "Design of Gasifiers to Optimize Fuel Cell Systems," Quarterly Report No. $8(07 / 1 / 92-09 / 30 / 92), 1992$.

Steinfeld, G.; "Design of Gasifiers to Optimize Fuel Cell Systems," Quarterly Report No. 9 (10/1/92 - 12/31/92), 1993. 


\section{APPENDIX A}

Summary of three case studies using catalytic gasification integrated with internal reforming carbonate fuel cells:

\section{CASE 1 RECOVERABLE GASIFICATION CATALYST WITH COLD GASL CLEANUP TECHNOLOGY}

The Case 1 configuration is based on a variation of the Exxon case (ECS) developed in the TAG II phase of the recent ERC/Fluor study ${ }^{(1)}$. The basic difference between the TAG II case and initial Case 1 is the source of hydrogen recycle gas fed to the gasifier. In the TAG II case the hydrogen recycle is a $\mathrm{H}_{2}$ and $\mathrm{CO}$ mixture separated from the clean syngas via a high pressure membrane. In Case 1 , the hydrogen recycle is pure hydrogen from the carbonate fuel cell anode exhaust separated using a Hydrogen Transfer Device (HTD).

The heat and material balance, along with a cost estimate, revealed that the initial Case 1 design was not competitive due to the high hydrogen recycle. The hydrogen recycle rate is dictated by the heat balance around the catalytic gasifier. Increasing the hydrogen recycle rate promotes the exothermic methanation reaction. Other gasifier conditions which also affect methanation, such as pressure, temperature, carbon conversion, steam and catalyst feed rates, were kept at the same values as in the TAG II Exxon case (ECS) in the 1990 study $^{(1)}$ and in the original Exxon design.

Five basic approaches were identified for reducing this hydrogen recycle rate:

- Adjust the gasifier operating conditions to promote methanation (i.e., higher pressure, lower temperature, and lower steam rate)

- Minimize the energy needed to heat up the reactants to gasification temperature, either by lowering the gasifier temperature or increasing the temperature of the steam and recycle gas. The latter alternative is severely limited by the availability of high temperature heat sources.

- Generate heat within the gasifier with the conventional addition of an oxidant.

- Use another technology to recycle hydrogen or carbon monoxide. This is most easily accomplished by using a membrane or PSA unit after the raw gas cleanup. These technologies use high pressure as the separation driving force and are therefore not expected to compete well with the HTD at low pressure.

- Utilize high temperature heat transfer. The temperature of the catalytic combustor outlet could be higher than the gasifier when high temperature catalytic combustor technology is available. 
A parametric evaluation was performed to gauge the impact of gasifier pressure, temperature, steam feed rate and oxidant (air) addition. Using these results a number of case configurations were then developed.

The final design configuration for Case 1 was chosen with respect to both heat rate and capital cost considerations. In general, the configurations with the better heat rate were also expected to have higher capital costs. After reviewing the heat rate results from this screening evaluation and qualitatively considering the capital cost impacts, the design which added a small amount of air to the gasifier and used an HTD for hydrogen separation from the carbonate fuel cell anode exhaust was selected.

Overall, Case 1 has a net power production of $174.1 \mathrm{MW}$ as compared with $150.9 \mathrm{MW}$ for the initial Case 1 design. With the same rate of coal input, this results in a heat rate reduction of $\sim 13 \%$. The improvement is due to the $51 \%$ reduction in consumption power, most of which is achieved by the reduced hydrogen recycle rate.

\section{CASE 1 PROCESS DESCRIPTION}

Figure A-1 is a detailed process flow sketch which shows the temperature, pressure, and mass flow rates of the major streams for Case 1. The Case 1 process is described in detail below.

\section{Coal Preparation and Catalyst Drying}

Illinois No. 6 coal is received into the plant and fed to integrated coal crushing and drying systems. These systems combine gas-swept impact mills with entrained drying columns. The coal is crushed to minus 8 mesh size and dried to $4.4 \mathrm{wt} . \%$ moisture on a dry coal basis. Flue gas is recirculated to supply heat and carrier gas for the drying columns. The gas is heated to $900^{\circ} \mathrm{F}$ in a single fired burner:

Catalyst from the catalyst recovery section is in the form of a concentrated water solution of 37 wt.\% equivalent of $\mathrm{K}_{2} \mathrm{CO}_{3}$. This is added to the crushed coal in a gentle mixing step using zig-zag blenders. The mixture is then dried in entrained columns. The heat for this drying step is supplied by recirculating flue gas and burning coal as in the first drying step. A total of $4.61 \%$ of the original coal feed is burned in both drying steps to supply the heat needed to dry the coal and catalyst slurry to a prescribed moisture level. The resulting prepared coal feed contains $15 \mathrm{wt} . \% \mathrm{~K}_{2} \mathrm{CO}_{3}$ and $4.4 \mathrm{wt} . \%$ moisture on a dry coal basis.

\section{Coal Gasification and AFBC}

The dried coal and catalyst mixture is pressurized via a lockhopper and fed into the bottom of the gasifier with dense phase pneumatic conveying. Superheated steam, recycled hydrogen, recycled raw gas, and air are introduced to the bottom of the gasifier. The coal and catalyst are maintained in a bubbling fluidized bed operating at $1200^{\circ} \mathrm{F}$ and 750 psia. Within the bed, $90 \%$ of the coal chars are converted to gas and the water-gas shift and methanation reactions proceed essentially to equilibrium. 


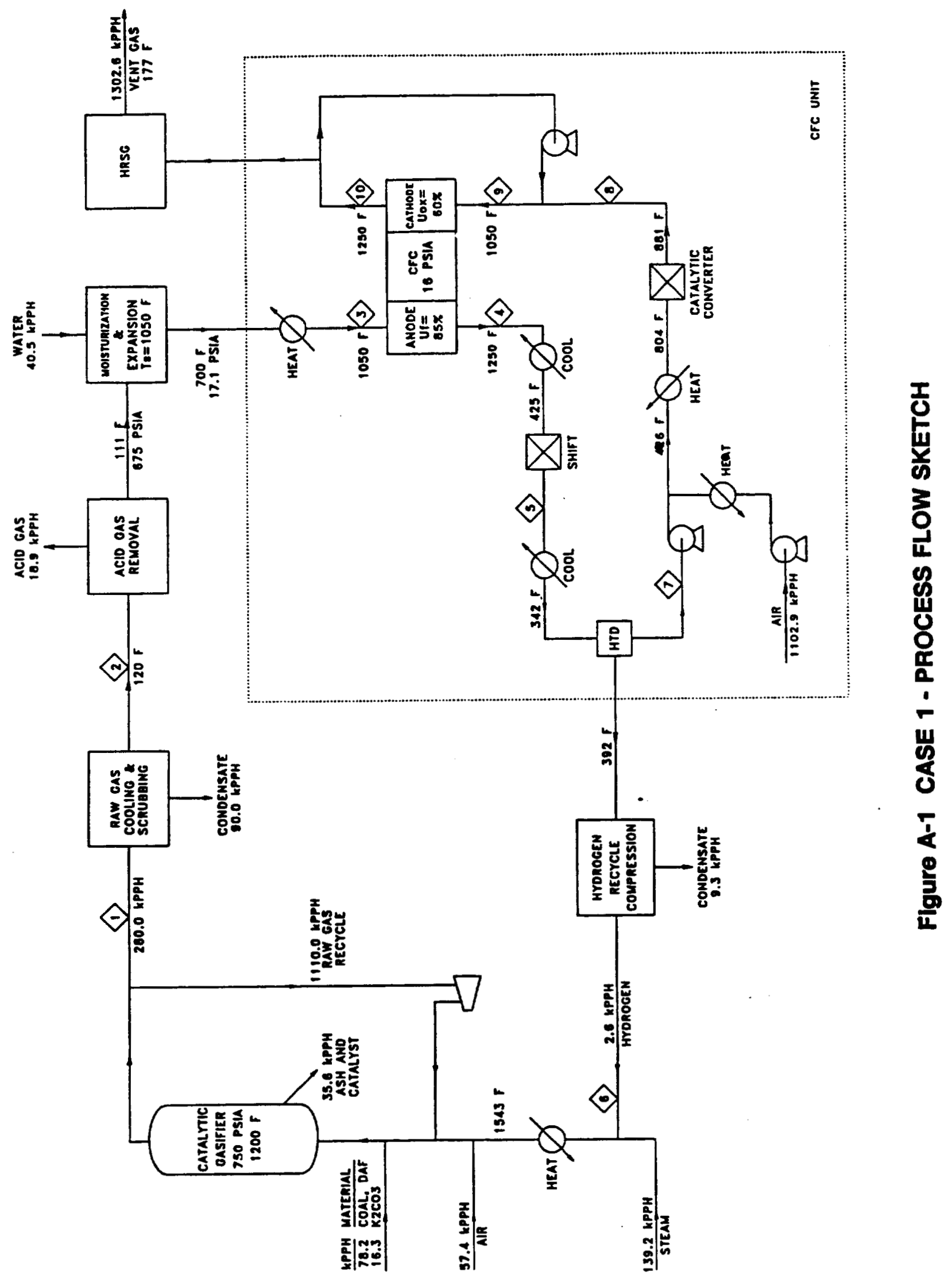


Unconverted coal chars together with the ash and spent catalyst are withdrawn from the bottom of the gasifier and routed to the atmospheric fluidized bed combustor (AFBC). Here the unconverted char is burned to completion to produce heat. This heat is used to preheat the steam and recycle hydrogen to $1543^{\circ} \mathrm{F}$, and to generate low pressure steam. The steam is originally generated by the HRSG at 815 psia and superheated to $750^{\circ} \mathrm{F}$. It is mixed with the recycle hydrogen stream from the carbonate fuel cell anode exhaust, via the hydrogen compression unit, before entering the AFBC.

Air enters the gasifier at 770 psia and $268^{\circ} \mathrm{F}$ after being compressed by a five stage centrifugal compression train. Interstage cooling is accomplished with cooling water.

The raw gas withdrawn from the top of the gasifier contains $17.0 \%$ methane, $3.3 \%$ carbon monoxide, $16.2 \%$ carbon dioxide, $13.8 \%$ hydrogen, and $36.4 \%$ water vapor. Most of this gas is recompressed back up to 770 psia and recycled to the gasifier, while a small portion (20.2\%) is routed downstream for raw gas cooling and scrubbing.

The raw gas recycle is necessary to provide a reasonable gasifier height. The height is dictated by the gasifier bed volume and diameter. The bed volume is set by the predicted carbon conversion kinetics while the diameter is set by the velocity limits of the fluidized bed. Raw gas is recycled through the gasifier in order to use a shorter, larger diameter gasifier while maintaining the required superficial bed velocity (1.1 fps). In this case, raw gas recycle changes the gasifier bed dimensions from an impractical 10.2' ID $x$ 463.6' $\mathrm{H}$ to $22^{\prime} \mathrm{ID} \times 100.2^{\prime} \mathrm{H}$. This change is expected to reduce the fabrication costs and pressure drop of the gasifier. The raw gas recycle compressor is required to operate at a high temperature $\left(1200^{\circ} \mathrm{F}\right)$ and high sulfur environment. Blowers for high temperature exist, but compressors for this service will have to be developed. The total power required for compression is $2.1 \mathrm{MW}$.

The gasifier vessel is built with low-alloy $(\mathrm{C}-1 / 2 \mathrm{Mo})$ steel using a 9-inch refractory lining. About 25 feet of freeboard is provided above the fluidized bed to minimize carry over. As a result, the 22 'ID $\times 100.2^{\prime} \mathrm{H}$ gasifier bed requires a $23^{\prime} 6{ }^{\prime \prime} I D \times 125^{\prime} 6 " \mathrm{~T}-\mathrm{T}$ gasifier vessel.

\section{Catalyst Recovery}

The process for catalyst recovery draws directly from the original Exxon design. Spent solids from the AFBC are mixed with aqueous $\mathrm{Ca}(\mathrm{OH})_{2}$ recycled from the catalyst recovery unit and fed into $\mathrm{Ca}(\mathrm{OH})_{2}$ digestion vessels operating at 70 psia and $300 \mathrm{~F}$. Here they are further mixed with feed lime $(\mathrm{CaO})$ and makeup $30 \mathrm{wt} \% \mathrm{KOH}$ solution. The $\mathrm{CaO}$ hydrolyzes in the digestors to form $\mathrm{Ca}(\mathrm{OH})_{2}$. The ratio of calcium in the lime feed to potassium in the feed char is maintained at $0.7 \mathrm{lb} \mathrm{Ca} / \mathrm{lb} \mathrm{K}$. The spent solids are soaked in the digestors for two hours. Each digester is equipped with a three-impeller agitator to maintain the solids in solution. Under these "digestion" conditions, $90 \%$ of the potassium in the spent solids is solubilized, the rest leaves with the solids in waterinsoluble compounds. Steam is added to the digestors to preheat the feed lime and makeup $\mathrm{KOH}$, and to maintain the operating temperature. 
The effluent slurry from the digestors is pumped through first stage hydroclones for solid/liquid separation. The overflow from the first-stage hydroclones, which is the most concentrated potassium solution in the system, contains $37 \mathrm{wt} \% \mathrm{~K}_{2} \mathrm{CO}_{3}$ equivalent. This is the recovered "rich" catalyst solution, and is fed to holding drums and pumped to the coal drying/catalyst addition section of the plant.

The first-stage hydroclone underflow slurry is mixed with the third-stage hydroclone overflow solution in the second-stage mixing drum. The mixed slurry from this vessel is pumped through the second stage hydroclones. The "semi-rich" overflow solution from this second stage is used to slurry the spent solids from the AFBC. The underflow from the second-stage hydroclones is fed into the third-stage mixing drum along with the overtlow from the fourth-stage hydroclones. This counter-current water-washing or "leaching" sequence continues until the fourteenth stage, where makeup wash water is preheated and added to the system. The leached solids in the last stage underflow are sent to solid waste handling.

\section{Raw Gas Scrubbing and Cooling}

As a cold gas cleanup system is used, the hot raw gas from the gasification unit must be cooled. The high temperature $\left(1200^{\circ} \mathrm{F}\right)$ raw gas is used to heat the carbonate fuel cell feed gas and the hot fuel gas expansion suction gas. Cooled to $537^{\circ} \mathrm{F}$, the raw gas is then routed through a contact scrubber to remove particulates. The scrubbed gas is passed through a catalytic COS hydrolysis reactor to convert the bulk of the COS to $\mathrm{H}_{2} \mathrm{~S}$. COS hydrolysis is required because the acid gas removal process, GAS/SPEC, only removes $50 \%$ of the COS. The converted gas, at $409^{\circ} \mathrm{F}$, is used to generate 100 psia steam and heat both the saturator recirculation water and steam system condensate. The raw gas is cooled to $100^{\circ} \mathrm{F}$ with cooling water before entering the GAS/SPEC unit.

\section{Acid Gas Removal (GAS/SPEC)}

Acid gas removal occurs as the scrubbed gas enters the Dow GAS/SPEC unit. Here the $100^{\circ} \mathrm{F}$ gas contacts Dow's proprietary MDEA solvent counter-currently on acid gas removal trays. Almost $100 \%$ of the $\mathrm{H}_{2} \mathrm{~S}$ and $50 \%$ of the COS is removed, along with $17 \%$ of the $\mathrm{CO}_{2}$. A small portion of the treated gas from the absorber is sent to the SCOT tail gas treating unit. The bulk of the treated gas enters an additional $\mathrm{H}_{2} \mathrm{~S}$ removal unit (PURASPEC) where the sulfur level is decreased to about $0.001 \mathrm{ppmv}$. The carbonate fuel cell unit requires a total sulfur level below $0.1 \mathrm{ppmv}$ in order to achieve reasonable catalyst life for the shift reactor.

The rich solvent from the absorber is heated by the hot regenerated solvent in the lean/rich solvent exchanger. The rich solvent is then directed to the regenerator for stripping dissolved gases, i.e., mainly $\mathrm{H}_{2} \mathrm{~S}, \mathrm{COS}$, and $\mathrm{CO}_{2}$. The regenerated (lean) solvent is cooled in the exchanger and in the lean solvent cooler, filtered to remove solids and organic contaminants, and stored in the solvent storage tank. The acid gases

stripped from the rich solvent are directed to the Claus unit for sulfur recovery. 


\section{Sulfur Recovery (Claus)}

The acid gas from the GAS/SPEC unit is routed to the Claus sulfur removal plant and SCOT tail gas treating process where $3174 \mathrm{lb} / \mathrm{hr}$ of elemental sulfur is produced. This sulfur production represents a recovery of about $73 \%$ of the sulfur entering with the coal, and the remaining $23 \%$ leaves with the gasifier ash as solid waste. Actual sulfur recovery per pass in the Claus plant is about $98.0 \%$ of the total sulfur entering the sulfur plant. Unrecovered sulfur is sent to the tail gas treating unit where sulfur is recovered as $\mathrm{H}_{2} \mathrm{~S}$ and is recycled to the sulfur plant.

The sulfur plant is a three-stage, acid gas, straight-through-type Claus unit. $\mathrm{H}_{2} \mathrm{~S}$ in the sour gas from the process water treating, the recycle from the tail gas plant, and one third of the acid gas from the GAS/SPEC unit is converted to $\mathrm{H}_{2} \mathrm{O}$ and $\mathrm{SO}_{2}$ in the sulfur furnace. Air for combustion is supplied by a blower. Heat from the combustion is recovered by generating 100 psia steam in the waste boiler. The exhaust gas from the waste heat boiler is mixed with the flow of acid gas that bypasses the furnace. The resultant gas mixture is fed to the sulfur converter No.1. The amount of gas bypassing the furnace is controlled to maintain a ratio of $\mathrm{H}_{2} \mathrm{~S}$ to $\mathrm{SO}_{2}$ slightly greater than 2:1 to force the converter reaction toward completion.

The exhaust gas/acid gas mixture passes through a three-step sulfur converter/condenser process. The gaseous sulfur produced in converter No.1 is condensed and recovered by cooling the effluent gas in sulfur condenser No. 1. Steam at 55 psia is generated by this cooling process. The sulfur condenses in the tubes and flows by gravity to either one of the concrete sumps. Sulfur, a solid at ambient temperatures, is kept molten by condensing 55 psia steam in pipe coils that cover the bottom of the sumps.

The gases from sulfur condenser No. 1 react further in sulfur converter No. 2. As in condenser/converter No. 1, the gaseous sulfur produced in the second converter is cooled and condensed in sulfur condenser No. 2. The cooling in this step is accomplished using the effluent gas from condenser No. 2. The condensed sulfur flows to the concrete sumps. The process is repeated in sulfur converter No. 3 and sulfur condenser No. 3.

Tail gas may contain sulfur in the form of $\mathrm{H}_{2} \mathrm{~S}$ with smaller amounts of $\mathrm{SO}_{2}, \mathrm{COS}$, and elemental sulfur. For final sulfur recovery, this gas flows through a tail gas coalescer and then enters the SCOT Unit.

\section{Tail Gas Treating (SCOT)}

The gas from the tail gas coalescer in the sulfur recovery unit contains unreacted $\mathrm{H}_{2} \mathrm{~S}, \mathrm{SO}_{2}, \mathrm{COS}$, and elemental sulfur species $\mathrm{S}_{6}$ and $\mathrm{S}_{8}$. Further processing in the Tail Gas Treating Unit removes these sulfur compounds.

The SCOT process is designed to first convert residual $\mathrm{SO}_{2}$ to $\mathrm{H}_{2} \mathrm{~S}$, then remove the $\mathrm{H}_{2} \mathrm{~S}$ from the atmospheric tail gas. Clean medium-BTU gas produced in the acid gas 
removal unit is used to supply both the hydrogen for the $\mathrm{SO}_{2}$ conversion and the heat needed for the reactions. A small portion of the clean medium-BTU gas is combusted in a fired heater, increasing the temperature of the tail gas to the required $550^{\circ} \mathrm{F}$. The hot gas goes to the hydrogenation reactor where the sulfur conversion reactions take place.

The effluent from the hydrogenation reactor is cooled in the waste heat boiler where 100 psia steam is generated. The partially cooled gas then passes through the water wash cooling tower where the gas is further cooled by direct contact with water.

Warm water from the bottom of the water wash cooling tower is pumped through a water-cooled exchanger. The cooled stream then reenters the top of the water wash cooling tower. A small stream of warm water from the bottom of the vessel is removed to maintain water balance in the unit. Cooled gas from the top of the water wash cooling tower enters the amine absorber where essentially all the $\mathrm{H}_{2} \mathrm{~S}$ is absorbed by countercurrent contact with an amine solution. Only a portion of the carbon dioxide is coabsorbed. The treated gas contains approximately $200 \mathrm{ppm}$ total sulfur.

Sulfur rich amine solution from the bottom of the absorber is pumped through the lean/rich solvent exchanger. Here it is heated by exchange with regenerated lean amine solution. Acid gases are stripped from the rich amine solution in the regenerator by application of indirect heat, supplied by condensing 100 psia steam in the regenerator reboiler. Regenerated lean amine solution is cooled via the lean/rich solvent exchanger and the lean solvent cooler prior to reentering the top of the amine absorber. Cooling in the lean solvent cooler is supplied by cooling water.

Acid gas from the regenerator overhead is cooled in the regenerator condenser, which uses cooling water to remove heat from the gas stream. Condensate is collected in the acid gas knockout drum and is refluxed to the regenerator. The acid gas is recycled to the Claus plant for sulfur recovery.

\section{Fuel Gas Moisturization}

Water is added to the clean fuel gas in order to inhibit the Boudouard reaction:

$$
2 \mathrm{CO} \rightarrow \mathrm{C}+\mathrm{CO}_{2}
$$

and thus prevent carbon deposition at the carbonate fuel cell anode. This is accomplished with a saturator column in order to use relatively low level heat to evaporate the water. Clean fuel gas at $110.5^{\circ} \mathrm{F}$ enters the bottom of the saturator. Water at a rate of $2245 \mathrm{lb}-\mathrm{mole} / \mathrm{hr}$ is absorbed by the fuel gas stream. The water exiting the bottom of the saturator is heated by low temperature raw gas coolers and then mixed with fresh boiler feed water (BFW) from the steam system. The moist gas exiting the top of the saturator is then routed to fuel gas expansion. 


\section{Hot Fuel Gas Expansion}

Clean 655 psia syngas from the fuel gas moisturizetion is heated from $348^{\circ} \mathrm{F}$ to $1050^{\circ} \mathrm{F}$, expanded across a turbine to around $95 \mathrm{psia}$, reheated from $650^{\circ} \mathrm{F}$ to $1050^{\circ} \mathrm{F}$, then expanded again to $17.1 \mathrm{psia}$. The expanded gas is fed to the carbonate fuel cell unit at $700^{\circ} \mathrm{F}$. The high suction temperature $\left(1050^{\circ} \mathrm{F}\right)$ maximizes power output by improving thermal efficiency. The fuel gas expanders produce $21.6 \mathrm{MW}, 11 \%$ of the total plant power.

The feed gas from the moisturization unit is heated from $348^{\circ} \mathrm{F}$ to $890^{\circ} \mathrm{F}$ against a high temperature raw gas. Heat from the HRSG is used to complete the fuel preheating and to accomplish the interstage heating. However, heat cannot be transferred directly from oxygen containing $1237^{\circ} \mathrm{F}$ carbonate fuel cell exhaust to the high pressure fuel gas due to the potential danger of explosion. Therefore, the heat is transferred using a secondary circulation loop of Olin's Solar Salt. This heat transfer fluid is a eutectic mixture of molten sodium nitrate and potassium nitrate (about $60 \mathrm{wt} \% \mathrm{NaNO}_{3}$ and $40 \mathrm{wt} \% \mathrm{KNO}_{3}$ ), with a maximum operating temperature of over $1,150^{\circ} \mathrm{F}$ and a melting temperature of $425^{\circ} \mathrm{F}$. The product has been tested extensively for the U.S. Department of Energy.

Hot fuel expanders with a service at $1050^{\circ} \mathrm{F}$ or above are not commercially available. Designs for high temperature blades and seals or cooling methods must continue to be developed.

\section{Carbonate Fuel Cells}

The expanded fuel gas at $17.1 \mathrm{psia}$ and $700^{\circ} \mathrm{F}$ is fed to the carbonate fuel cell unit. As shown in Figure A-1, the carbonate fuel cell unit includes the fuel cell stacks, a low temperature shift reactor, hydrogen transfer device (HTD), catalytic combustor, DC/AC invertor and various blowers and heat exchangers. Overall, the unit consumes fuel gas and air and produces flue gas, recycle hydrogen and $83.8 \%$ of the total electrical power output.

The total heat loss to the atmosphere from the carbonate fuel cell equipment and piping is $30 \mathrm{MMBtu} / \mathrm{hr}$. Overall, $80.7 \mathrm{MMBtu} / \mathrm{hr}$ of heat needs to be transferred from the HRSG and Raw Gas cooling unit to the carbonate fuel cell unit.

- Carbonate Fuel Cell Stacks

The expanded fuel gas is heated from $700^{\circ} \mathrm{F}$ to $1050^{\circ} \mathrm{F}$ against high temperature raw gas then fed to the anode side of the internal reforming carbonate fuel cell stacks. Within the anode hydrogen is consumed by the half reaction:

$$
\mathrm{H}_{2}+\mathrm{CO}_{3}^{-2} \rightarrow \mathrm{H}_{2} \mathrm{O}+\mathrm{CO}_{2}+2 e^{-}
$$

Methane and carbon dioxide are converted to hydrogen via the reforming and shift reactions. The anode exhaust gas composition $\left(54.4 \% \mathrm{CO}_{2}, 32.0 \% \mathrm{H}_{2} \mathrm{O}, 3.6 \% \mathrm{H}_{2}\right.$, $3.3 \% \mathrm{CO}$ and $6.6 \% \mathrm{~N}_{2}$ ) is close to a reforming and shift equilibrium composition. 
On the cathode side, carbon dioxide and oxygen are consumed by the cathode half reaction:

$$
\frac{1}{2} \mathrm{O}_{2}+\mathrm{CO}_{2}+2 \mathrm{e}^{-}-\mathrm{CO}_{3}^{-2}
$$

Carbonate ions continuously migrate across the electrolyte to the anode to maintain the chemical balance and transfer electrical charge.

The carbonate fuel cell is designed for a fuel utilization of $85 \%$, an oxygen utilization of $60 \%$ and a cell voltage of 0.74 volts. It produces $168.8 \mathrm{MW}$ of DC power and has a current density of 165.5 ASF. A total of 864 fuel cell stacks, each containing about $2862^{\prime} \times 3^{\prime}$ cells, are required for a total active fuel cell area of 1.38 million square feet.

- Shift Reactor and Hydrogen Transfer Device

The anode exhaust gas is routed through a shift reactor and Hydrogen Transfer Device (HTD) in order to separate out the hydrogen. The separated hydrogen is recycled back to the gasifier via the hydrogen compression unit. The hydrogen depleted gas is mixed with air and fed to the catalytic combustor.

The HTD is in essence a phosphoric acid fuel cell operating in reverse, consuming DC power to separate hydrogen. The hydrogen is consumed by the anode reaction:

$$
\mathrm{H}_{2} \rightarrow 2 \mathrm{H}^{+}+2 \mathrm{e}^{-}
$$

and produced by the cathode reaction:

$$
2 \mathrm{H}^{+}+2 \mathrm{e}^{-} \rightarrow \mathrm{H}_{2}
$$

Like phosphoric acid fuel cells, the HTD operates at about $400^{\circ} \mathrm{F}$ and is poisoned by high levels of $\mathrm{CO}$. As the carbonate fuel cell anode exhaust contains $3.3 \mathrm{~mole} \% \mathrm{CO}$, a low temperature shift reactor is placed upstream of the HTD in order to consume the bulk of the $\mathrm{CO}$ via the water-gas shift reaction:

$$
\mathrm{CO}+\mathrm{H}_{2} \mathrm{O} \rightarrow \mathrm{H}_{2}+\mathrm{CO}_{2}
$$

Anode exhaust is cooled from $1250^{\circ} \mathrm{F}$ to $425^{\circ} \mathrm{F}$ by transferring heat to the catalytic converter feed gas and carbonate fuel cell air. The cooled gas is then fed to the low temperature shift reactor. In this adiabatic reactor, water-gas shift 
conversion decreases the $\mathrm{CO}$ content of the exhaust to $0.20 \%$, an acceptable level for the HTD. This also increases the temperature of the gas to $482^{\circ} \mathrm{F}$, a temperature recommended by the vender to maximize shift conversion. The bed was designed for a 1 psi pressure drop.

The shifted gas is cooled to $342^{\circ} \mathrm{F}$ by transferring heat to the carbonate fuel cell air intake, and then fed to the HTD. The HTD recovers $79.5 \%(1280 \mathrm{lb}-$ moles/hr) of the hydrogen from the anode exhaust. The hydrogen rich stream contains $71.1 \% \mathrm{H}_{2}$ and $28.9 \% \mathrm{H}_{2} \mathrm{O}$. The hydrogen depleted stream contains only $1.5 \%$ hydrogen. Both streams exit the HTD at $392^{\circ} \mathrm{F}$, resulting in a heat loss of 4.8 MMBtu to the environment. The HTD consumes $3.65 \mathrm{kWh} / \mathrm{lb}-\mathrm{mole}$ of hydrogen transferred for a total DC consumption of $4.7 \mathrm{MW}$.

- Carbonate Fuel Cell Air Intake, Catalytic Converter and Cathode Recycle Blower

The hydrogen depleted exhaust gas is routed through a blower to boost the pressure from $14.25 \mathrm{psia}$ to $16.3 \mathrm{psia}$. The blower discharge is mixed with $426^{\circ} \mathrm{F}$ carbonate fuel cell air and heated to $804^{\circ} \mathrm{F}$ against the hot anode exhaust gas. The heated gas is then fed to a catalytic converter. The catalytic converter combusts the residual $\mathrm{CO}$ and $\mathrm{H}_{2}$ to produce $\mathrm{CO}_{2}$ required for the downstream carbonate fuel cell cathode. A catalytic type burner is required due to the low heating value of the HTD exhaust gas.

The hot $\left(881^{\circ} \mathrm{F}\right)$ converter outlet gas is mixed with the cathode recycle gas and fed to the carbonate fuel cell cathode. This feed gas has a temperature of $1050^{\circ} \mathrm{F}$ and a composition of $16.0 \% \mathrm{CO}_{2}, 9.8 \% \mathrm{O}_{2}, 12.9 \% \mathrm{H}_{2} \mathrm{O}$, and $61.3 \% \mathrm{~N}_{2}$. At an oxygen utilization of $60 \%$, the cathode outlet composition is $9.5 \% \mathrm{CO}_{2}, 6.8 \% \mathrm{O}_{2}$, $14.5 \% \mathrm{H}_{2} \mathrm{O}$, and $69.2 \% \mathrm{~N}_{2}$. The cathode outlet flow is split: $58 \%$ is recycled back to the cathode inlet via the cathode recycled blower, $42 \%$ is fed to the HRSG. The recycle blower consumes a total power of $1.0 \mathrm{MW}$.

Carbonate fuel cell air intake is composed of filtered ambient air which is compressed to $16.8 \mathrm{psia}$ and $90^{\circ} \mathrm{F}$. The air is preheated to $258^{\circ} \mathrm{F}$ against the HRSG, to $370^{\circ} \mathrm{F}$ against the HTD feed gas, and to $426^{\circ} \mathrm{F}$ against the anode exhaust gas.

- DC/AC Converter

As fuel cells produce $D C$ power, a $D C / A C$ power invertor is required to provide $A C$ power for export. The invertor is sized to convert the DC power produced from the carbonate fuel cell less the DC power consumed by the HTD. With an overall inversion efficiency of $97 \%$, a total of $159.2 \mathrm{MW}$ is inverted.

\section{Hydrogen Compression}

The rich hydrogen stream from the carbonate fuel cell unit is cooled to $90^{\circ} \mathrm{F}$ using cooling gas whereby some of the water condenses out of the gas phase. The gas 
stream is then compressed in a multi stage reciprocating compressor to a final pressure of 785 psia and $267^{\circ} \mathrm{F}$. Between stages, the gas stream is cooled to $90^{\circ} \mathrm{F}$ by cooling water. The total power required for compression is $2.4 \mathrm{MW}$.

\section{Heat Recovery Steam Generator (HRSG)}

The exhaust gas from the carbonate fuel cell unit is routed to the HRSG for heat recovery. The HRSG provides a total duty of $378.4 \mathrm{MMBtu} / \mathrm{hr}$, which is shared by the molten salt for the hot gas expander, 815 psia steam generation, boiler feed water superheating, and carbonate fuel cell air preheating. The stack gas exits to the atmosphere at $177^{\circ} \mathrm{F}$, assuming a unit loss of $2 \%(7.7 \mathrm{MMBtu} / \mathrm{hr})$.

\section{Steam and Condensate Systems}

The steam and condensate systems use waste heat from the process units to generate process steam and hot water, provide steam heating, and produce electrical power with a condensing turbine. Condensate is recirculated through a deaerator to the steam generators. Figure A-2 illustrates the steam balance.

From the deaerator, 940 psia boiler feed water (BFW) is preheated to $495^{\circ} \mathrm{F}$ in the HRSG. A portion is used to provide hot make-up water to raw gas cooling and fuel gas moisturization and to generate superheated $800 \mathrm{psia}, 750^{\circ} \mathrm{F}$ steam in the HRSG. Most of the superheated steam is routed to the catalytic gasifier, the rest is fed to a condensing turbine.

The steam turbine is a multistage expander utilizing 100 psia steam injection and a surface condenser. First stage suction uses $750^{\circ} \mathrm{F}, 800$ psia superheated steam into which a small amount of 100 psia steam is injected. The net power produced is 10.1 MW. The discharge is condensed in the surface condenser operating at 2.5 inches of $\mathrm{Hg}$. The surface condenser cooling duty of $21.8 \mathrm{MMBtu} / \mathrm{hr}$ is provided by cooling water.

Demineralized water is added to the condensate and the mixture is pumped to the condensate storage and polishing. The polished condensate is heated to $195^{\circ} \mathrm{F}$ in the HRSG, mixed with the condensate from the 100 psia steam user, then routed to the deaerator.

The 100 psia and 55 psia steam producers are provided with BFW from the deaerator. The bulk of the 100 psia steam is routed to 100 psia steam users, the rest is split between the steam injection for the condensing turbine and steam stripping for the deaerator. The balance of the stripping steam is provided by the 55 psia steam producers and steam from the condensate and blowdown flash drums. The deaerator is required to remove $\mathrm{CO}_{2}$ and $\mathrm{O}_{2}$. It operates at 25 psia. 


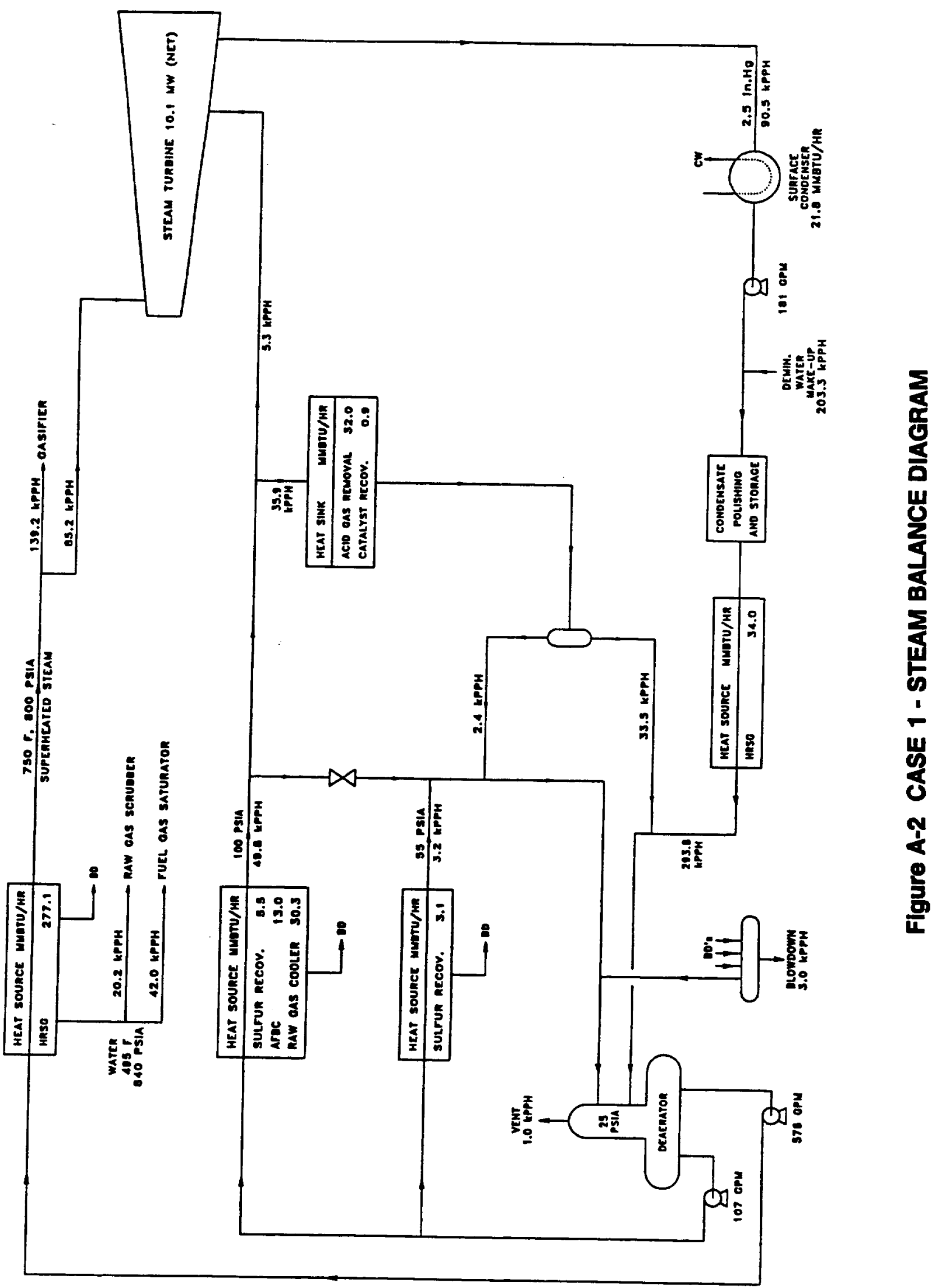




\section{CASE 2 DISPOSABLE CATALYST/ COLD GAS CLEAN-UP}

In an effort to make the catalytic gasification process more economically feasible, the use of disposable gasification catalysts was investigated. A literature search was conducted by the University of North Dakota/Energy \& Environmental Research Center ${ }^{(9)}$ in order to provide recommendations for disposable catalyst options.

Case 2 differs from Case 1 in the use of relatively low cost, disposable limestone $\left(\mathrm{CaCO}_{3}\right)$ as the gasification catalyst instead of recoverable potassium carbonate $\left(\mathrm{K}_{2} \mathrm{CO}_{3}\right)$. The use of a disposable catalyst was intended to lower plant capital cost by eliminating the catalyst recovery equipment and reducing make-up chemical costs. However, this would be offset by an increase in the gasification cost as limestone is less effective than $\mathrm{K}_{2} \mathrm{CO}_{3}$ as a gasification catalyst.

A process sketch of this configuration is shown in Figure $A-3$ where the flow diagram is identical to Case 1 , with differences in the material and energy balance. The design impacts using this configuration are discussed below.

\section{Catalyst Handling}

Using a disposable catalyst significantly simplifies the catalyst handling equipment. Limestone is received and stored as a solid containing $95 \% \mathrm{CaCO}_{3}$. At a rate of 140 tons/day, the catalyst is crushed, mixed with dried coal, and pneumatically conveyed to the gasifier. The ash and spent catalyst leaving the atmospheric fluidized bed combustor (AFBC) is routed directly to slag storage.

Because limestone is received as a solid, the catalyst and coal drying equipment is significantly smaller than Case 1 , and the coal feed to the drying furnace is reduced by $45 \%$. As a result, the total "as received" coal feed to the plant fell by $2.5 \%$.

\section{Gasifier Size}

Limestone catalyst is not as effective as $\mathrm{K}_{2} \mathrm{CO}_{3}$ in promoting the steam carbon gasification reactions. Hence, the gasification bed volume must be increased by about a factor of two in order to achieve the same $90 \%$ conversion. Due to this increase in bed volume, the limestone catalyzed gasifier requires two gasification trains, each with a 22'ID $\times 161^{\prime}$ total height gasifier. In comparison, Case 1 uses one train with a 23.5'ID $\times 125^{\prime}$ total height gasifier. Differences in diameter are due to requirements of fluidization and differences in recycle rates.

The additional gasifier train results in an increase in the total heat loss from the gasification unit to the environment, from $25 \mathrm{MMBtu} / \mathrm{hr}$ to $51 \mathrm{MMBtu} /$ hour.

\section{Gasifier Air Rate}

As a result of the increased heat loss from the gasifier, the gasification air feed rate has increased by $45 \%$. Increasing the air feed to the gasifier generates more heat from 


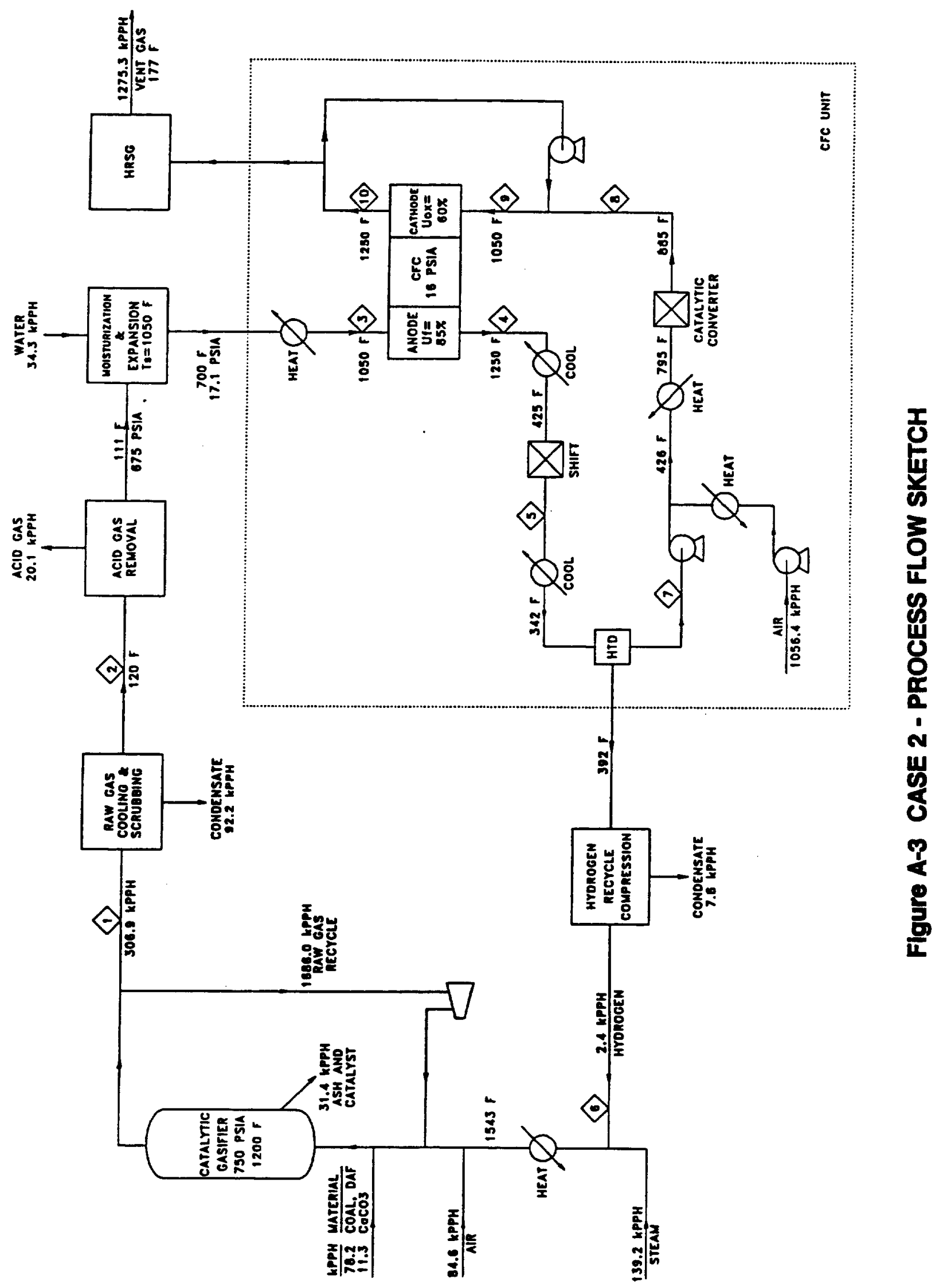


the exothermic partial oxidation reactions, but also increases the size of the downstream equipment by 4 to $10 \%$, with the exception of the fuel cell. At the fuel cell, less power is produced because the feed gas has a lower heating value.

\section{CASE 3 DISPOSABLE CATALYST/HOT GAS CLEAN-UP}

Case 3 is similar to Case 2 with the use of a disposable catalyst, but differs from both Case 1 and 2 by using a hot, zinc ferrite cleanup system. Figure A-4 is a process sketch of the Case 3 configuration showing the same flow sheet with hot cleanup and the appropriate material and energy balance data. The design repercussions of the hot gas cleanup system are discussed below.

\section{Hot Gas Cleanup System}

In the hot gas cleanup system, the $1200^{\circ} \mathrm{F}$ raw gas is first routed through a ceramic filter to remove particulates and then passed through a disposable nahcolite chloride guard bed. From the guard bed, the gas is directed to one of two zinc ferrite beds where the bulk of the sulfur is adsorbed. While one bed captures the sulfur, the other bed is regenerated with steam and air. The $1250^{\circ} \mathrm{F}$ regeneration gas, with sulfur in the form of $\mathrm{SO}_{2}$, is routed back to the gasifier where the sulfur is adsorbed.

The relatively clean syngas is cooled to $700^{\circ} \mathrm{F}$ and passed through a disposable zinc oxide bed. This polishing bed lowers the sulfur concentration to $0.35 \mathrm{ppmv}$ for the carbonate fuel cell. Further reduction was added for the hydrogen transfer device (HTD). A disposable CuO polishing bed was added upstream of the shift reactor to further reduce the sulfur content to the acceptable level of $0.01 \mathrm{ppmv}$. This bed was not required with cold gas cleanup systems.

After passing through the zinc oxide bed, the clean fuel is heated to $1050^{\circ} \mathrm{F}$ and routed to hot fuel gas expansion. The moisture level of this gas is acceptable (35.2\%) and therefore fuel gas moisturization is not required to prevent carbon deposition. 


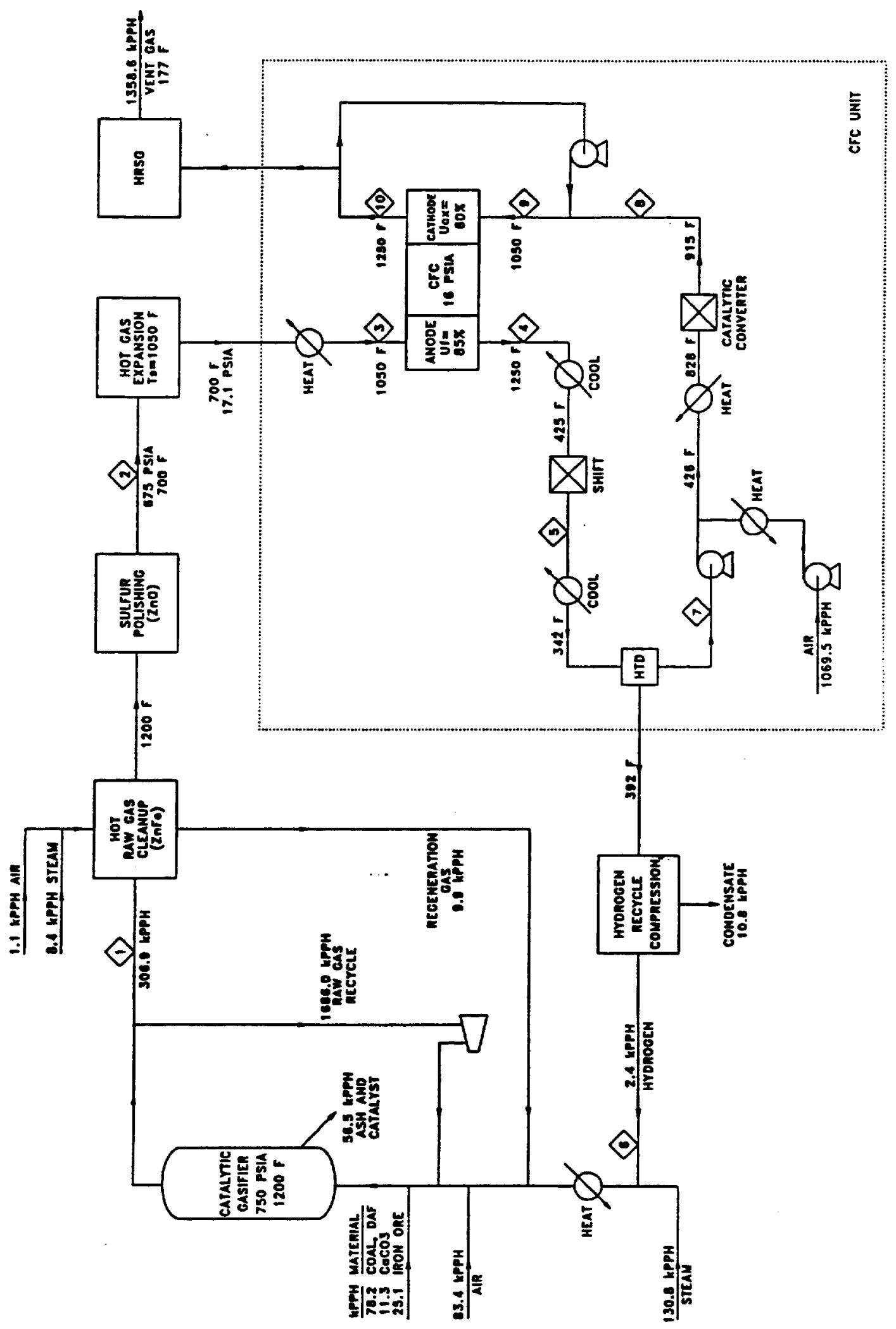

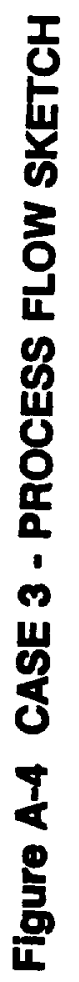




\section{CASE COMPARISON}

A comparison of the gasifier design parameters for the different configurations show that the increased air flow to the disposable gasification catalyst systems (Case 2 and 3 ) lowers the cold gas efficiency $-3 \%$. As stated earlier, the lower reactivity of the disposable gasification catalyst doubles the number of gasifiers needed, each with more than $12 \%$ increase in bed volume over the gasifier designed for the recoverable gasification catalyst used in Case 1.

The total annual cost for catalyst and chemicals for the disposable gasification catalyst/hot gas cleanup configuration (Case 3) is slightly greater than the recoverable gasification catalyst/cold gas cleanup configuration (Case 1) and more than 3 times greater than the disposable gasification catalyst/cold gas cleanup configuration (Case 2). The high cost stems mainly from the zinc ferrite bed used in the cleanup and the taconite tailings used in the gasifier.

A detailed heat rate and power summary of the three cases is shown in Table A-1. As indicated, the heat rate of Case 3 is $6,377 \mathrm{Btu} / \mathrm{kWh}, 3.6 \%$ lower than Case $1(6,606$ Btu/kWh). This improvement is the result of increased fuel gas expansion power from the higher gas flow. The heat rate for Case 2 is $6,705 \mathrm{Btu} / \mathrm{kWh}, 1.5 \%$ higher than for Case 1 . This increase primarily stems from higher gasifier heat loss.

A relative cost comparison between Case 1 and 2 was performed. The cost of each unit was estimated from the April 1990 TAG II study. The capital costs for Case 2 is predicted to be $1.4 \%$ higher than for Case 1. The 1990 ERC/Fluor study gave a cost comparison between coal gasification/carbonate fuel cells power plants using cold cleanup and hot cleanup. One of the conclusions from that study was that the capital cost of the design using hot gas cleanup was $-7 \%$ lower than the cold gas cleanup configuration.

The relative capital cost comparison for Cases 1 and 2 indicate that the cold gas cleanup units (Raw Gas Cooling and Scrubbing, Acid Gas Removal, and Sulfur Recovery) comprise about $9 \%$ of the total capital cost. If these units were eliminated and replaced with the hot gas cleanup reactors, the total capital cost could conceivably drop by $7 \%$. Based on these two data points, the capital cost for Case 3 is assumed to be $7 \%$ lower than Case 2, but still 1.3\% higher than Case 1. These percentages further assume that the same contingency is applied to each case. If a more detailed analysis were to be performed, Case 3 would likely be assigned a higher contingency because the hot gas cleanup technology is less developed than the cold gas cleanup processes.

The relative cost of electricity (COE) between Case 1 and 2 was calculated. In this evaluation, the COE for Case 1 was based on the TAG II Exxon catalytic system (ECS) Case $^{(1)}$. The calculated COE for Case 2 was approximately one-third higher than the COE for Case 1. The COE for Case 3 is over $4 \%$ lower than for Case 2 and over $3 \%$ lower than for Case 1, indicating the potential advantage of hot gas cleanup. 


\section{Table A-1 \\ POWER SUMMARY AND \\ HEAT RATE COMPARISON}

\begin{tabular}{|c|c|c|c|}
\hline $\begin{array}{l}\text { Case } \\
\text { Gas Cleanup Technology } \\
\text { Catalyst }\end{array}$ & $\begin{array}{c}\text { Case } 1 \\
\text { Cold } \\
\mathrm{K}_{2} \mathrm{CO}_{3} \\
\end{array}$ & $\begin{array}{c}\text { Case 2 } \\
\text { Cold } \\
\mathrm{CaCO}_{3} \\
\end{array}$ & $\begin{array}{c}\text { Case } 3 \\
\mathrm{Hot} \\
\mathrm{CaCO}_{3}+\mathrm{Fe} \\
\end{array}$ \\
\hline 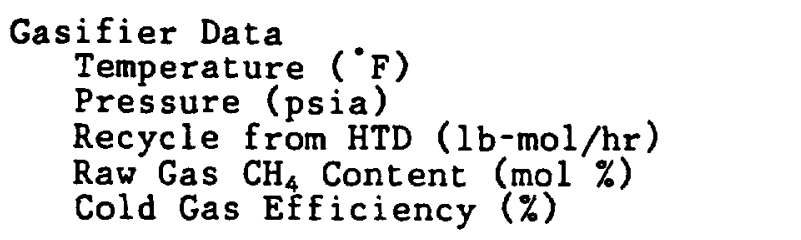 & $\begin{array}{r}1,200 \\
750 \\
1,282 \\
17.0 \\
92.9\end{array}$ & $\begin{array}{r}1,200 \\
750 \\
1,154 \\
14.9 \\
90.1\end{array}$ & $\begin{array}{r}1,200 \\
750 \\
1,154 \\
14.9 \\
90.1\end{array}$ \\
\hline Heat Rate, HHV (Btu/kWh) & 6,606 & 6,748 & 6,377 \\
\hline Efficiency, HHV $(\xi)$ & $51: 7$ & 50.6 & 53.5 \\
\hline $\begin{array}{l}\text { Power Summary (MW) } \\
\text { Production } \\
\text { Carbonate Fuel Cell } \\
\text { Fuel Gas Expander } \\
\text { Steam Turbine } \\
\text { Total Production } \\
\text { Consumption } \\
\text { HTD } \\
\mathrm{H}_{2} \text { Recycle Gas Compression } \\
\text { Gasifier Air Compression } \\
\text { Raw Gas Recycle Compression } \\
\text { Cathode Recycle Blower } \\
\text { Carbonate Fuel Cell Air Blower } \\
\text { Carbonate Fuel Cell Anode Blower } \\
\text { Steam and Cooling Water } \\
\text { Other } \\
\text { Total Consumption } \\
\text { Net Power Production }\end{array}$ & $\begin{array}{r}163.9 \\
21.6 \\
10.1 \\
195.5 \\
\\
4.7 \\
2.4 \\
4.1 \\
2.1 \\
1.0 \\
2.4 \\
2.3 \\
1.6 \\
0.8 \\
21.5 \\
174.1 \\
\end{array}$ & $\begin{array}{r}156.3 \\
22.4 \\
11.0 \\
189.8 \\
\\
4.2 \\
2.2 \\
6.0 \\
3.1 \\
1.0 \\
2.3 \\
2.3 \\
1.7 \\
0.8 \\
23.7 \\
166.1 \\
\end{array}$ & $\begin{array}{r}158.1 \\
29.7 \\
11.4 \\
199.2 \\
\\
4.2 \\
2.2 \\
6.0 \\
3.1 \\
0.9 \\
2.4 \\
2.6 \\
1.2 \\
0.8 \\
23.5 \\
175.7 \\
\end{array}$ \\
\hline $\begin{array}{l}\text { Coal Data, "as received" } \\
\text { Consumption }(1 \mathrm{~b} / \mathrm{hr}) \\
\text { Gasifier } \\
\text { Coal Dryer Furnace } \\
\text { Total } \\
\text { Total Consumption (TPD) } \\
\text { HHV (Btu/lb) }\end{array}$ & $\begin{array}{r}108,592 \\
5,250 \\
113,842 \\
1,366 \\
10,100\end{array}$ & $\begin{array}{r}108,592 \\
2,366 \\
110,958 \\
1,331 \\
10,100\end{array}$ & $\begin{array}{r}108,592 \\
2,366 \\
110,958 \\
1,331 \\
10,100\end{array}$ \\
\hline
\end{tabular}




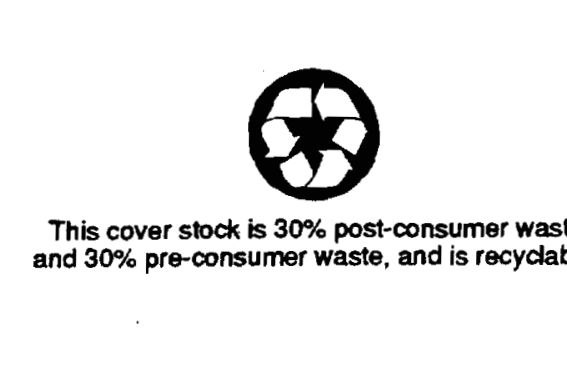




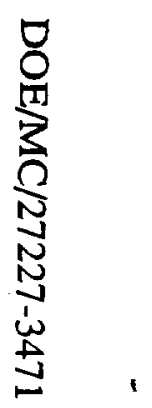

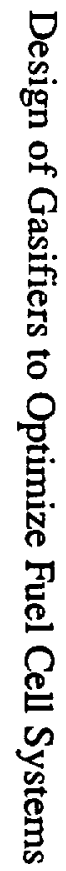

